\title{
The importance of gobies (Gobiidae, Teleostei) as hosts and transmitters of parasites in the SW Baltic
}

\author{
C. D. Zander, U. Strohbach \& S. Groenewold \\ Zoologisches Institut und Zoologisches Museum, Universität Hamburg; Martin-Luther- \\ King-Platz 3, D-W-2000 Hamburg 13, Federal Republic of Germany
}

\begin{abstract}
The parasite fauna of five goby species (Gobiidae, Teleostei) was investigated in the Baltic Sea during the period 1987 to 1990.13 parasite species were found in samples from the Lübeck Bight: Bothriocephalus scorpii, Schistocephalus sp. (Cestoda); Cryptocotyle concavum, Cryptocotyle lingua, Podocotyle atomon, Derogenes varicus (Digenea); Hysterothylacium sp. (cf. auctum), Contracaecum sp., Anisakis simplex (Nematoda); Corynosoma sp., Echinorhynchus gadi, Neoechinorhynchus rutili, Pomphorhynchus laevis (Acanthocephala). The number of parasite species were: 10 in the sand goby Pomatoschistus minutus, 8 in the black goby Gobius niger, 7 in the two-spotted goby Gobiusculus flavescens, 6 in the common goby Pomatoschistus microps, and 5 in the painted goby Pomatoschistus pictus. Neoechinorhynchus rutili occurred only in P. minutus, and Corynosoma sp. only in $G$. niger. The extent to which the gobies were parasitized clearly depended on the respective ways of life and, moreover, on the kind of prey ingested by the hosts. Additionally, the age of the hosts might be important. The highest rate of parasitism, more than $60 \%$, was reached by Hysterothylacium sp. in $G$. niger and by Cryptocotyle concavum in P. microps. Infestation incidence lay mostly below $40 \%$ which means a satellite species status (Holmes, 1991). The number of parasite species was highest in summer; the highest intensities of single parasites occurred in spring (Podocotyle atomon) or autumn (Cryptocotyle concavum). Bothriocephalus scorpii, $\mathrm{Hy}$ sterothylacium sp. and Podocotyle infested their juvenile hosts very early, but only Hysterothylacium was accumulated by $G$. niger during its whole life span, whereas Bothriocephalus persisted also in older gobies in low intensities. The cercariae of Cryptocotyle spp. penetrate actively into their hosts; all the other parasites named were transmitted in larval form by prey organisms which consisted mainly of planktonic and benthic crustaceans. The gobies were final hosts for only 5 parasites; but two species may be transmitted to larger fish, and 6 species to sea birds or mammals. The parasite community of the five gobies may possibly be taken to characterize the ecological quality of the environment of the Lübeck Bight.
\end{abstract}

\section{INTRODUCTION}

Teleosts of the family Gobiidae play an important role within the ecosystems of the North and Baltic Seas (Fonds, 1973; Hesthagen, 1977; Thormann \& Wiederholm, 1983; Evans, 1984; Zander \& Hagemann, 1986; Zander, 1988; Hamerlynck et al., 1990). Regarding food chains, the gobies are secondary consumers and are themselves prey for larger fish (Markowski, 1935; Arntz, 1974), sea birds (Hartwig \& Söhl, 1975; Doornbos, 1984) and seals (Behrens, 1985; Sievers, 1989). Their availability to fish eating predators implies that they are important transmitters of parasites which perform their life cycles in several hosts (Zander et al., 1984; Zander \& Döring, 1989). Within the complicated cycles 
of digeneans, cestodes and nematodes, the gobies are frequently second intermediate hosts (Zander, 1988; Zander \& Westphal, 1991).

It was Reimer (1970), in particular, who propagated the investigation of parasites in the Baltic Sea. He studied the helminths of 47 invertebrates as well as those of 27 fish species, with regard to morphology, ontogeny and taxonomy, thereby discovering new life cycles and areas of distribution. Several authors thereafter studied the parasitic faunas of single fish hosts (e.g. Möller, 1975; Køie, 1983), or the host spectra of single parasites (Køie, 1979; Zander et al., 1984).

Therefore it might be of interest to now provide a detailed study of parasites in a certain area of the Baltic Sea. Five goby species from the shallow waters of the Lübeck Bight were regarded as hosts. These may be called a guild (Root, 1967). The helminths of the taxa Digenea, Cestoda, Acanthocephala and Nematoda are considered, because their abundances as parasites are highest. The studies focussed on the following: (1) Analysis of the helminth species in regard to incidences and specificities within the goby guild. (2) Tracing of developmental cycles, including thereby the first and second invertebrate intermediate hosts. (3) Knowledge of structure and dynamics of a fish-parasite community in brackish waters. (4) Elaboration of parameters of a parasite community in order to characterize the respective habitat.

The five hosts are Gobius niger L., which is the only longer-living goby on this site with a short pelagic period, and four species that live approx. one year: Pomatoschistus minutus (Pallas), 6-7 cm long, a large species with a longer larval period; Pomatoschistus microps (Krøyer) and Pomatoschistus pictus (Malm) with shorter pelagic phases; and Gobiusculus flavescens (Fabricius) which lives suprabenthically during its whole life. All the investigated fishes were caught between 1987 and 1990, some G. niger before 1987 . The studies were complemented by studies on specimens of snails (Littorina and Hydrobia), on planktonic and benthic Crustacea (Gammarus, Jaera) which were all collected during 1990. These investigations may provide further information on the structure and dynamics of the Lübeck Bight ecosystem which has been under observation since 1983 (Zander \& Hagemann, 1986, 1987; Melander, 1989; Zander \& Döring, 1989; Zander, 1990; Zander, 1991).

\section{INVESTIGATION SITE, MATERIAL AND METHODS}

\section{Investigation site}

Diverse host organisms were collected near the beacon of Dahmeshöved situated between the sea resorts of Kellenhusen and Dahme, Lübeck Bight, Baltic Sea. This site has been covered since 1983 by SCUBA investigations on the role of small-size fish within the Baltic ecosystem. A stony pier extends from the beach approximately $30 \mathrm{~m}$ in an easterly direction and then continues for about $100 \mathrm{~m}$ in a northerly direction parallel to the shore. Its foundation lies in $2-3 \mathrm{~m}$ water depth. The pier is adjacent to a wide sand bottom, followed by a clay ecotone with pebbles and boulders in 5-6 $\mathrm{m}$ water depth.

Water temperature and salinity values fluctuate during the course of a year, as was found earlier (Zander, 1990): Salinity is between 9 and $15 \%$; water temperature reaches $20^{\circ} \mathrm{C}$ at the most (Fig. 1). 


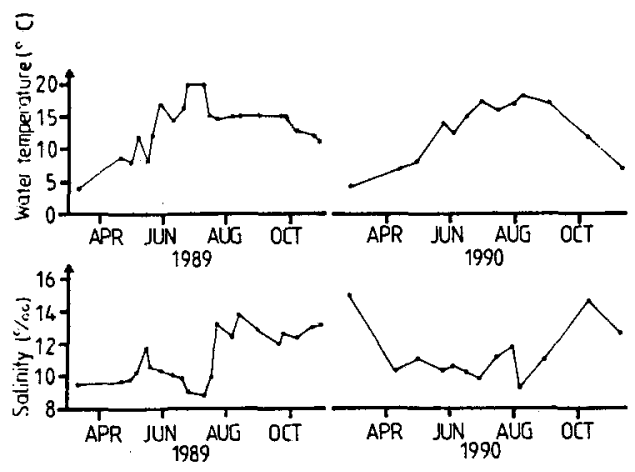

Fig. 1. Seasonal fluctuations of water temperature (above) and salinity (below) at Dahmeshöved during 1989 and 1990

\section{Methods}

The gobies were caught every 4-6 weeks from early spring to late autumn at the pier and in the clay ecotone by means of SCUBA and by hand-nets (Table 1). The fish were fixed in $4 \%$ Formalin for further examinations. The plankton was sampled directly at the pier by pouring $100 \mathrm{l}$ seawater through a net of $55 \mu \mathrm{m}$ mesh; in summer 1990 some qualitative samples were added. The concentrated organisms were fixed in $4 \%$ Formalin. Benthic crustaceans were quantitatively obtained by scratching an area of $156 \mathrm{~cm}^{2}$ from the Mytilus girdle of the pier. The aufwuchs together with its mobile fauna was collected in a plastic-bottle and fixed in $4 \%$ Formalin directly after the diving operation. The snails were collected at a water depth of 2-3 m. By means of a measuring rope, several areas of $0.25 \mathrm{~m}^{2}$ were marked where all Littorina saxatilis were counted. The Hydrobia spp. were quantitatively sampled by means of a hand net, $20 \mathrm{~cm}$ wide and of $1 \mathrm{~mm}$ mesh, which was drawn over $0.5 \mathrm{~m}$ on the sand substrate. All snails were transported alive to the laboratory for further examinations.

The fixed fish were measured, wet weighed and intensively inspected externally, including the gills. Then the body cavity was opened, the intestinal tract cut off at the esophagus and the end of the rectum, externally inspected and finally opened in full

Table 1. Numbers of five goby species in the samples off Dahmeshöved examined in the years 1983-1990

\begin{tabular}{|c|c|c|c|c|c|c|}
\hline Species & $\begin{array}{c}\text { Before } \\
1987\end{array}$ & 1987 & 1988 & 1989 & 1990 & Sum \\
\hline Pomatoschistus minutus & & 84 & 138 & 107 & 177 & 506 \\
\hline Pomatoschistus pictus & & & 1 & 1 & 25 & 27 \\
\hline Pomatoschistus microps & & & & 75 & 3 & 78 \\
\hline Gobiusculus flavescens & & & 10 & 135 & 16 & 161 \\
\hline Gobius niger & 34 & 1 & 7 & 22 & 39 & 103 \\
\hline Sum & 34 & 85 & 156 & 340 & 260 & 875 \\
\hline
\end{tabular}


length. The content of the intestinal tract was transferred to investigation dishes, the prey organisms classified according to the relevant taxonomical units, and the parasites determined to the species level. Additionally, the body cavity, liver and kidney were inspected for parasites.

The copepods were selected from the plankton samples and transferred to a fluid consisting of $70 \%$ ethanol, $25 \%$ water and $5 \%$ glycerine, completed by $1-2$ drops of borax-carmine. The identification of species and their infestation with parasites was carried out under a microscope. The taxonomical classification of parasites is difficult, so that only "larval stages" were determined. The snails were investigated alive; the shells of $L$. saxatilis were broken by pliers, the visceral mass drawn onto a microscope slide. Regarding Hydrobia, 10 specimens were simultaneously pressed between 2 microscope slides and examined in the original medium. The sporocysts, rediae or cercariae present were at first studied alive, but were then transferred to a mixture of alcohol-glycerine, and determined as far as possible to the species level. The benthic crustaceans were selected from the aufwuchs samples which contained mainly Mytilus edulis. In particular, Gammarus spp. and Jaera albifrons were investigated to discover whether these harbour parasite larvae or cysts. Those found were also classified as far as possible to the species level.

The following indices were calculated:

(1) Evenness

$$
\mathrm{J}=\frac{\mathrm{H}_{\mathrm{s}}}{\ln \mathrm{S}},
$$

where $\mathrm{H}_{\mathrm{s}}=$ Shannon-Wiener Index, $\mathrm{S}=$ number of species.

(2) Renkonen Index

$$
\text { RI } \%=100 \cdot\left(\mathrm{pr}_{1}+\mathrm{pr}_{2} \ldots+\mathrm{pr}_{\mathrm{n}}\right) \text {, }
$$

where $\mathrm{pr}_{1-\mathrm{n}}=$ the minor values of two compared hosts regarding infestation by parasite species 1 to $\mathrm{n}$.

(3) S pecificity Ind ex according to Rohde (1982)

$$
S I=\Sigma \frac{x(i, j)}{n(j) \cdot h(i, j)}: \Sigma \frac{\times(i, j)}{n(j)},
$$

where $x(i, j)=$ number of parasite specimen of species $i$ in host species $j ; n(j)=$ number of host specimen of species $j ; h(i, j)=$ range of host species $j$ infested by parasite $i$.

(4) Affinity Index

$$
A I=N(i, j) \cdot \frac{1}{B(j) \cdot B(i, j)},
$$

where $N(i, j)=$ part of double infestation with parasite species $i ; B(j)=$ part of infested hosts of species $j ; B(i, j)$ part of host species $j$ parasitized by species $i$.

\section{RESULTS}

\section{Spectrum of parasite species}

The mean incidence of parasitic infestation (percentage of infested hosts) of the five goby species fluctuated during the period 1989 and 1990 between $85 \%$ (Pomatoschistus 
microps) and $40 \%$ (Pomatoschistus minutus). As the other three species were infested to at least $64 \%$ (Gobiusculus flavescens), the sand goby is at the bottom of this scale (Fig. 2). Within the goby guild, 13 parasites were found (Fig. 3):

Cestoda: Bothriocephalus scorpii (Müller, 1776)

Schistocephalus sp.

Digenea: Podocotyle atomon (Rudolphi, 1802)

Cryptocotyle concavum (Creplin, 1825)

Cryptocotyle lingua (Creplin, 1825)

Derogenes varicus (Müller, 1784)

Nematoda: Hysterothylacium sp. (cf. auctum (Rudolphi, 1802)

Anisakis simplex (Rudolphi, 1809)

Contracaecum sp.

Acanthocephala: Echinorhynchus gadi Müller, 1776

Pomphorhynchus laevis (Müller, 1776)

Neoechinorhynchus rutili (Müller, 1780)

Corynosoma sp.

High infestation incidences are only found in a few parasite-host systems, e.g. Cryptocotyle concavum in $P$. microps; Cryptocotyle lingua in Gobius niger; Podocotyle

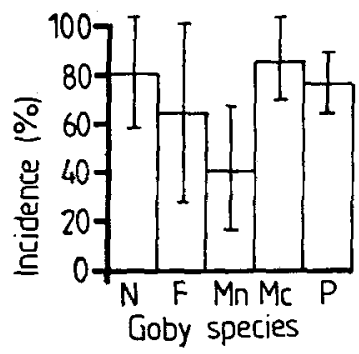

Fig. 2. Mean infestation incidence (\%) of 5 goby species: $\mathrm{N}=\mathrm{G}$. niger, $\mathrm{F}=\mathrm{G}$. flavescens, $\mathrm{Mn}=$ $P$. minutus, $\mathrm{Mc}=P$. microps, $\mathrm{P}=P$. pictus. The vertical bars give the mean standard deviations

atomon in G. flavescens, P. minutus and Pomatoschistus pictus; and Hysterothylacium sp. in $G$. niger (Fig. 3). Only one host was infested by $N$. rutili ( $P$. minutus) or by Corynosoma sp. (G. niger); only two hosts by 4 parasite species (Fig. 4). However, Hysterothylacium sp. and Podocotyle atomon are present in all five gobies, whereas Bothriocephalus scorpii was found in all species excepting P. microps (Fig. 4).

Infestations of $P$. minutus were investigated in several cycles of more than three years. From 1988, the parasite spectrum comprising 6 species changed to comprise 8 in 1989, of which 4, however, were new and 2 had vanished. The parasite fauna of the sand goby of 1990 is identical with that of 1988 . This may mean that the investigation of twoyear cycles is sufficient to record the parasites of a host.

\section{Seasonal incidence and intensity of infestation}

The two-axes graphs, used here for the presentation of the incidence as well as the intensity of infestation, illustrate the importance of the respective parasites (Figs 5-7). Intensive investigations were carried out on Pomatoschistus minutus covering three and 


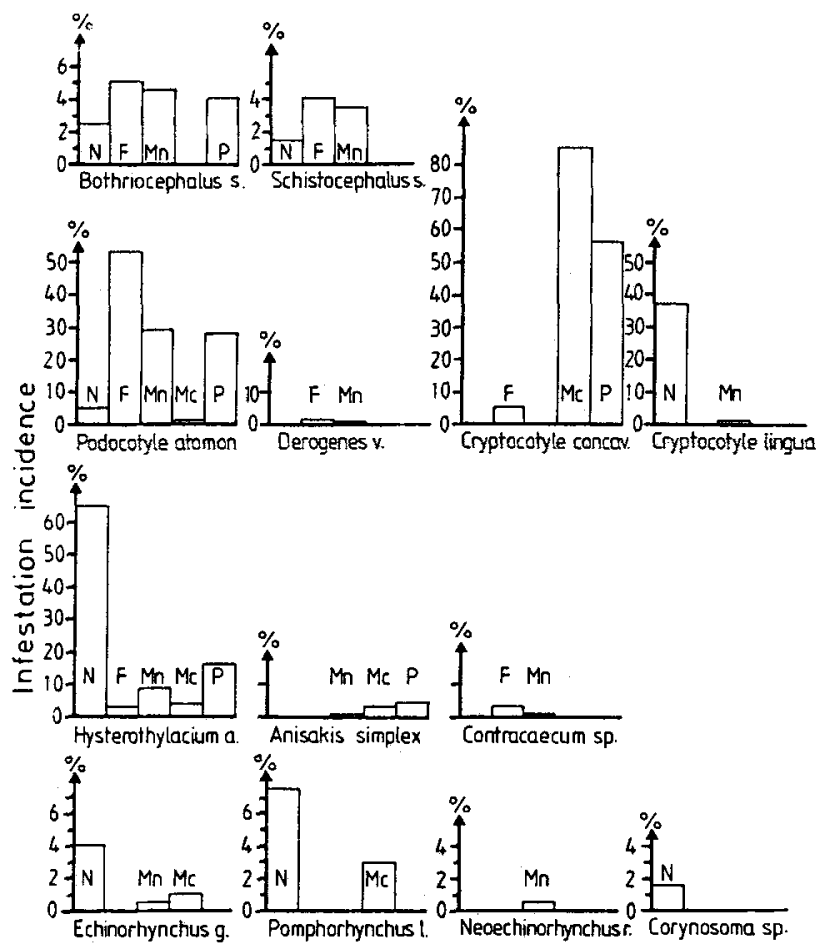

Fig. 3. Infestation incidence (\%) of goby hosts by 13 different parasite species. Gobies: $\mathrm{N}=G$. niger, $\mathrm{F}=G$. flavescens, $\mathrm{Mn}=P$. minutus, $\mathrm{Mc}=P$. microps, $\mathrm{P}=P$. pictus

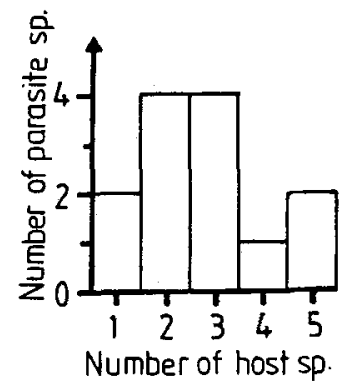

Fig. 4. Specificity of 13 parasite species according to their presence in 1-5 goby hosts

a half years (Fig. 5). Podocotyle atomon was the most abundant parasite in late spring and in summer with a maximal incidence of $95-98 \%$ and intensity of $95 \%$. Bothriocephalus scorpii was found in spring and autumn at low rates of intensity; the other cestode, Schistocephalus sp., was present at a relatively high incidence rate in late summer and autumn. Hysterothylacium occurs during the whole year but at a low rate of intensity (Fig. 5). The other parasites play only a minor role; however, $P$. minutus is the goby host with the widest parasite spectrum (Fig. $11 \mathrm{f}$ ). 


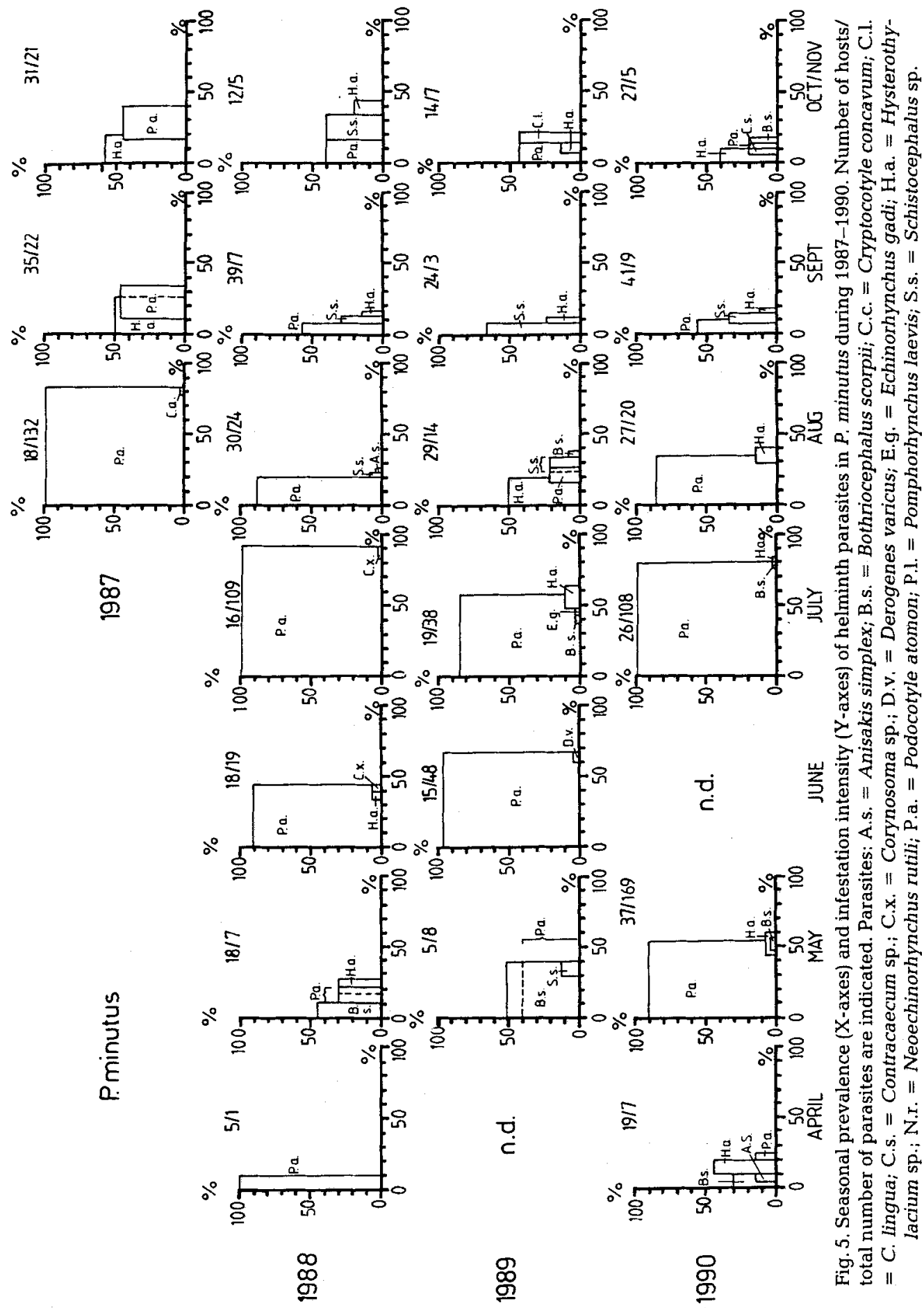




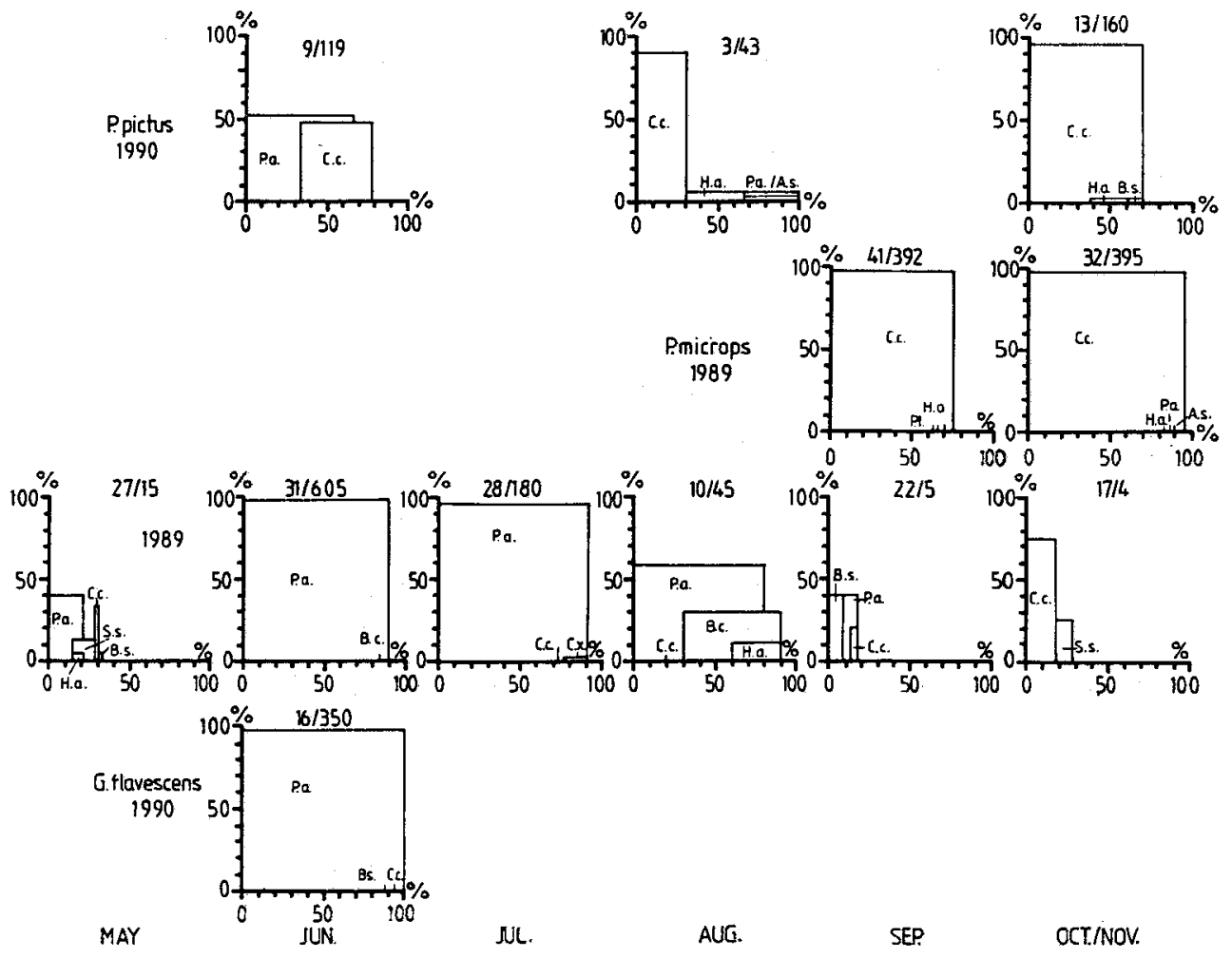

Fig. 6. Seasonal prevalence ( $\mathrm{X}$-axes) and infestation intensity ( $\mathrm{Y}$-axes) of helminth parasites found in $P$. pictus, $P$. microps and G. flavescens in 1989 and/or 1990. Number of hosts/total number of parasites are indicated. For explanation of abbreviations denoting parasites, see Fig. 5
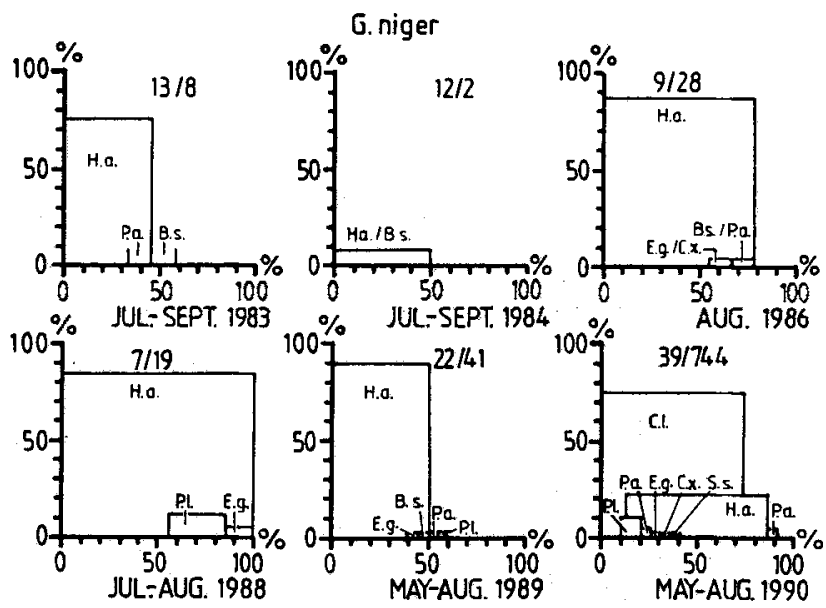

Fig. 7. Infestation incidence; (X-axes) and infestation intensities (Y-axes) of helminth parasites in G. niger investigated over 6 years. Number of hosts/total number of parasites are indicated. For explanation of abbreviations denoting parasites, see Fig. 5 
$G$. flavescens presents the same trends as $P$. minutus regarding infestation with $P$. atomon but with even higher intensities (Fig. 6). Additionally, Cryptocotyle concavum is regularly found during the whole year but at low rates of incidence. This parasite dominates in the kidneys of Pomatoschistus microps which are riddled with metacercarial cysts in autumn, and in Pomatoschistus pictus where they settle mainly in the skin (Fig. 6). P. pictus reveals seasonal changes in its parasite community: $P$. atomon and $C$. concavum are present in a balanced relation in spring, whereas $C$. concavum dominates in summer and autumn with continuously increasing intensity. Other parasites are seldom present in P. pictus (Fig. 6).

Gobius niger is the only longer living species of the goby guild from Dahmeshöved. During the six years investigated, it was found in summer and sometimes also in spring (Fig. 7). Hysterothylacium sp., determined as Hysterothylacium auctum when adult, occurs frequently and intensively. Podocotyle atomon, however, plays only a minor role. In 1990, dermal cysts of Cryptocotyle lingua were highly apparent (Fig. 7). Remarkably, 3 Acanthocephala were found to infest $G$. niger which is the only intermediate host for Corynosoma sp.

\section{Burden of parasite specimens}

Pomatoschistus pictus and Gobius niger reveal a mean infestation rate of 13 parasite specimens, Pomatoschistus microps of 10 , Gobiusculus flavescens of 8 , but Pomatoschistus minutus clearly differs from the other gobies in harbouring only 2 parasites (Fig. 8 ). The reasons may lie in the respective seasonalities of the parasite species (Fig.9). Podocotyle is very abundant in $G$. flavescens but also in $P$. pictus and $P$. minutus in spring and early summer, whereas Cryptocotyle is found with high intensities in $P$. microps and $P$. pictus during summer and autumn (Fig. 9).

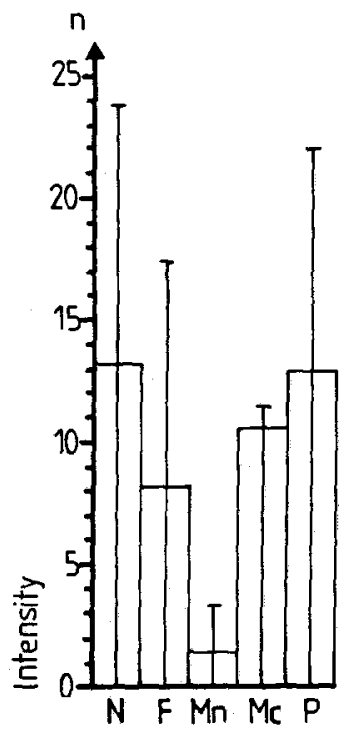

Fig. 8. Infestation intensity during 1989 and 1990 expressed as mean number of parasites per goby species ( $\mathrm{x}$-axis: $\mathrm{N}=G$. niger, $\mathrm{F}=$ Gobiusculus flavescens, $\mathrm{Mn}=P$. minutus, $\mathrm{Mc}=P$. microps, $\mathrm{P}=P$. pictus). The solid line scale gives the standard deviations 


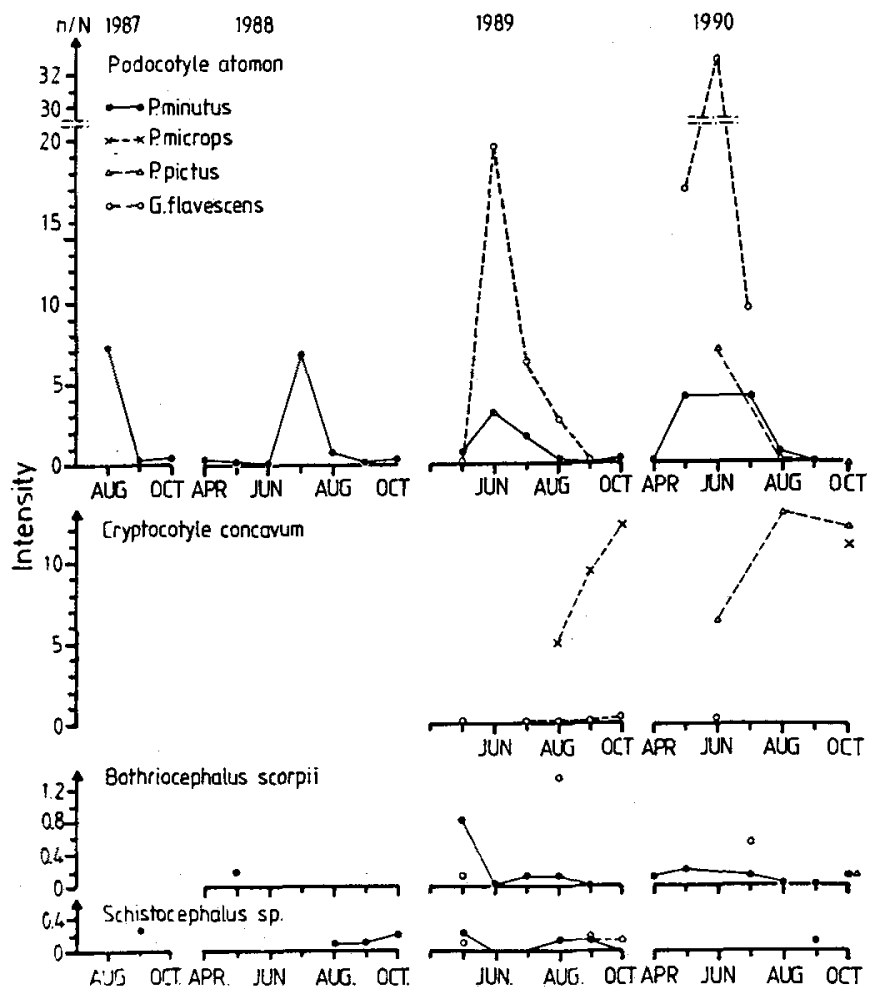

Fig. 9. Seasonal fluctuations in the infestation intensity of four parasite species in four goby hosts during 1987-1990 related to the total number of investigated hosts

The two cestodes are of much lesser abundances than the digeneans. Bothriocephalus scorpii seems to have maximal values in May ( $P$. minutus) or in summer (G. flavescens [Fig. 9]). Schistocephalus sp. infests $G$. flavescens in spring as well as in autumn, at a low but almost identical level.

Selected examples of the single host-parasite relationship are presented in Figure 10. Podocotyle atomon is present in G. flavescens and $P$. minutus, usually with 4-7 individuals, whereas Cryptocotyle concavum is concentrated in P. microps with 8-15 specimens. Some $G$. flavescens were found to be infested by more than $128 P$. atomon, or some $G$. niger by more than 128 Cryptocotyle lingua (Fig. 10).

\section{Species burden and diversity}

The relation of parasite species to the number of all host individuals was studied, whether these were infested or not, which creates relatively low values (Fig.11). Pomatoschistus minutus bears the highest burden in late spring, but the lowest in April and autumn. However, Gobiusculus flavescens as well as Pomatoschistus pictus surpass these values in summer and autumn (Fig. 11a). The mean species burden of 1989 and 1990 is highest in Gobius niger, attaining, as in P. pictus and Pomatoschistus microps, more than 1, but lowest in P. minutus with the value of only 0.5 (Fig. 11b). 

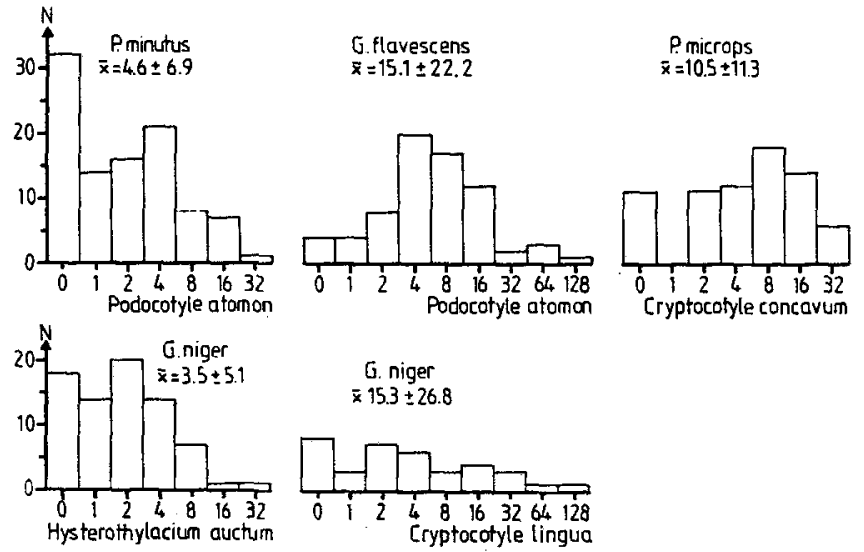

Fig. 10. Distribution of host specimens depending on increasing parasite intensities which are arranged on a geometrical scale. $\overline{\mathrm{x}}=$ mean rate of intensity \pm standard deviation

Regarding evenness, a contrasting tendency to that of the species burden is visible (Fig. 11c). The only exceptions are G. flavescens in August and P. pictus in June, when high species burden as well as high evenness values occur. The mean evenness of 0.6 of $P$. minutus may demonstrate a balanced parasite community in this host (Fig. 11d). The mean values of the other gobies are clearly lower, indicating especially in G. flavescens and $P$. microps, unbalanced parasite communities (Fig. 11d).

The highest numbers of parasite species were found in G. flavescens in May 1989 (5), whereas they were lower (2-3) in the other hosts or in other months (Fig. 11e). Minimal values are found every summer in $P$. minutus; these are combined with different evenness values in the individual years. The sum of all parasites which occur in the course of a year is greater than that found in the monthly samples (Fig. 11f). This means that the parasites change during the seasons in a species-specific manner: $P$. minutus thus harbours up to 10, but $P$. pictus only 5, parasites (Fig. 11f).

\section{Parasites of hosts of different age groups}

An analysis of parasites in the different size classes of Pomatoschistus minutus, Pomatoschistus microps and Gobius niger seems to be opportune, considering the sufficient number of specimens of these species present (Fig. 12). The sizes of hosts and the extent to which they are parasitized are significantly correlated in $G$. niger and $P$. minutus but not in $P$. microps, where the larger specimens are parasitized to a lesser extent than the smaller ones (Fig. 12a). The same trend is visible when the intensities of Cryptocotyle concavum are considered (Fig. 12b). Podocotyle atomon may be a pioneer species in P. minutus, as are C. concavum in P. microps and Hysterothylacium in G. niger (Fig. 12b). Additionally, an increasing number of parasites occur in the larger size classes with low intensities (Fig.12c). The number of parasite species increases during the growth of $G$. niger as well as of $P$. minutus, whereas evenness decreases as a result of the dominance of the main parasites (Fig. 12d). In P. microps, however, the different sized classes do not present clear differences. 

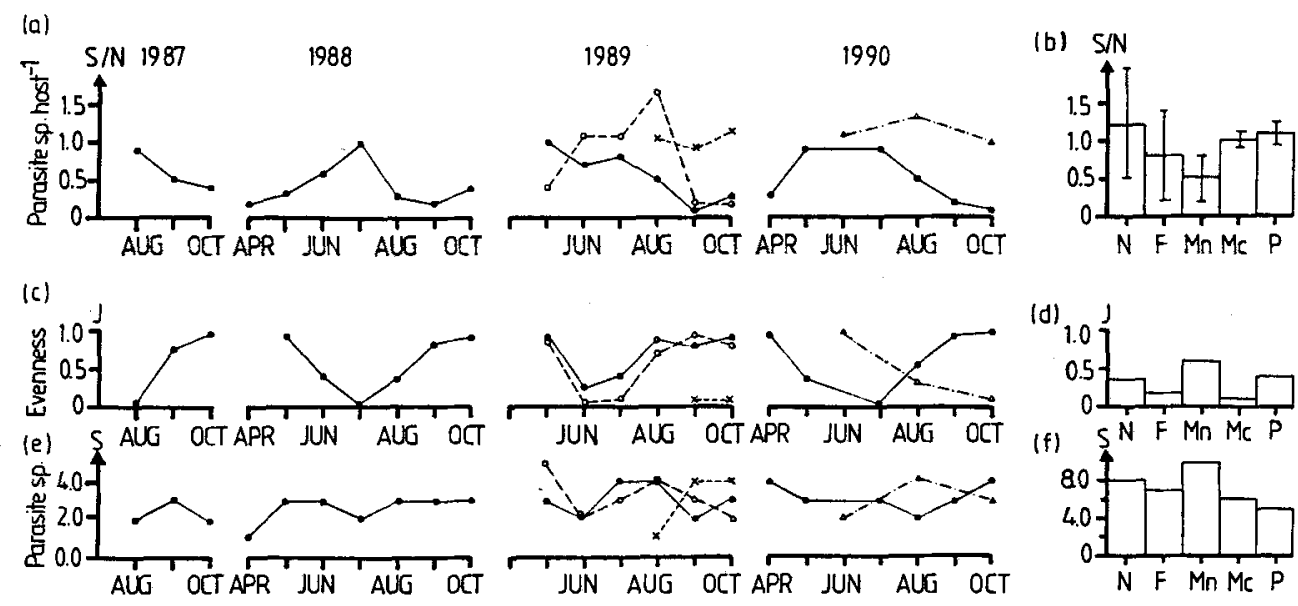

Fig. 11. Seasonal fluctuations $(a, c, e)$ and mean values $(b, d, f)$ of helminth parasites in five goby hosts during 1989/1990. a and b: parasite species burden; $c$ and d: evenness; $e$ and f: number of parasite species. Bars in Fig. $11 \mathrm{~b}$ give standard deviations. Gobies: $\mathrm{N}=G$. niger, $\mathrm{F}=\mathrm{G}$. flavescens, $\mathrm{Mn}=P$. minutus, $\mathrm{Mc}=P$. microps, $\mathrm{P}=\mathrm{P}$. pictus. Symbols: full circles $=P$. minutus, open circles $=$ $G$. flavescens, crosses $=P$. microps, triangles $=P$. pictus (see Fig. 9 )

\section{Macro- and microhabitats}

The cladograms of the Renkonen indices indicate highest similarities between Pomatoschistus microps and Pomatoschistus pictus, and also between Gobiusculus flavescens and Pomatoschistus minutus in the species composition of parasites (Fig. 13). The same trends are apparent when intensities are compared and, in the case of $P$. microps/P. pictus, when infestation incidence is regarded. All three parameters reveal the special position of Gobius niger (Fig. 13). However, P. pictus presents also accords with $P$. minutus and $G$. flavescens with regard to incidence of infestation. Therefore the painted goby may probably play an intermediate role within the goby guild.

A further analysis follows Rohde (1982) who calls the habitat of host the macrohabitat, and the site within the host where the parasite lives the microhabitat. By means of the specificity index, slight preferences are found here for distinct goby hosts by the 13 parasites, because no value lies below 0.6 (Table 2). The maximal value of 1 calculated for Cryptocotyle lingua in $G$, niger means that the black goby is preferred by this parasite. Hysterothylacium sp. and Podocotyle atomon which are present in all 5 gobies reveal higher indices with regard to density, but lower indices with regard to frequency (Table 2). This may lie in the strong preference for $G$. niger by the nematode and for G. flavescens by the digenean. The lowest indices are found in Bothriocephalus scorpii whose infestation rates are almost identical, with the exception of G. niger. In most cases, only one host is preferred: $P$. microps by Cryptocotyle concavum, $G$. flavescens by cestodes, and $G$. niger by 3 of the 4 acanthocephalan species. This was already demonstrated by the respective infestation incidence (Fig. 3).

The microhabitats conform in 9 of the 13 parasites in all goby hosts. $B$. scorpii and Neoechinorhynchus rutili are found in the stomach, Derogenes varicus in the midgut, and 
(a)

Pminutus P.microps

G.niger
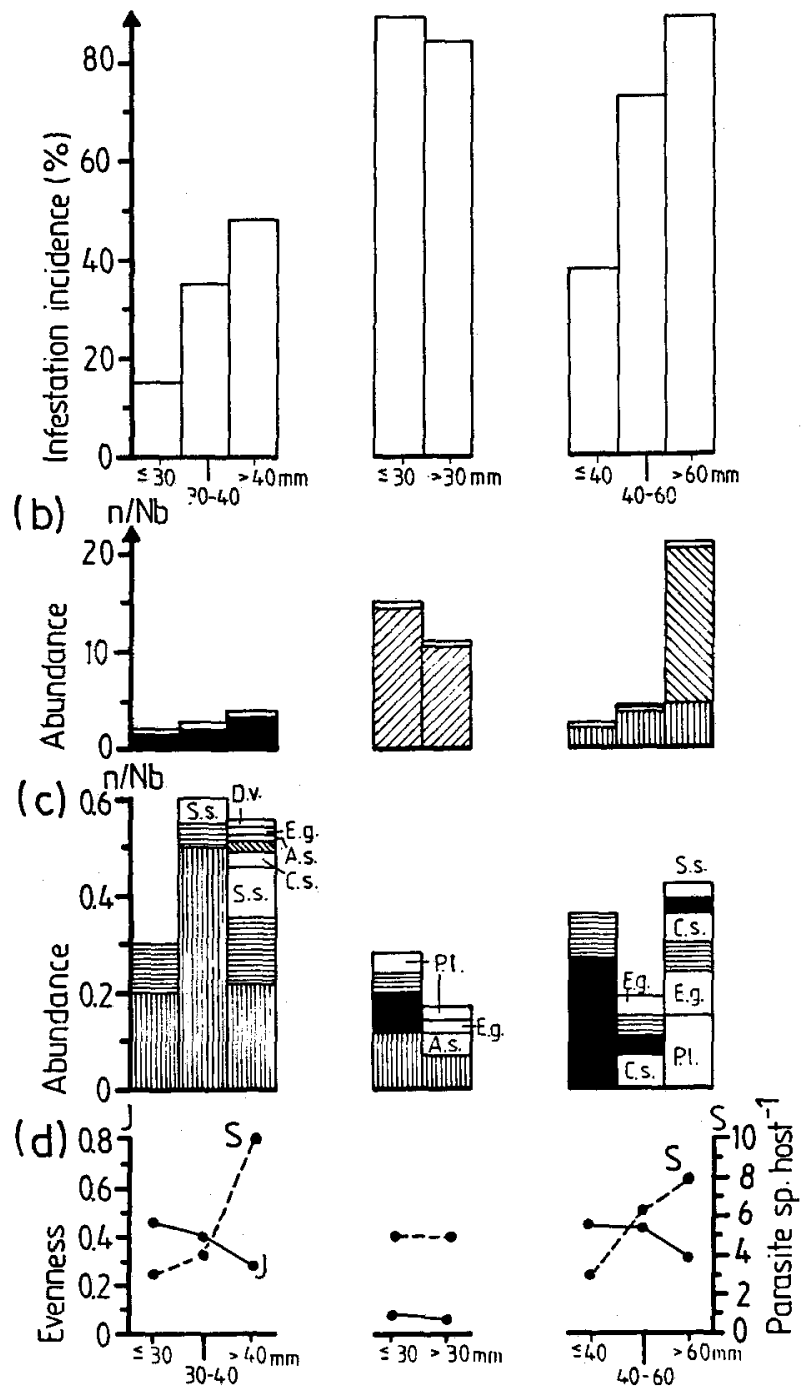

P.atomon

C. concavum

C.linguo

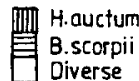

Fig. 12. Infestation of different size classes of three goby species. a: infestation incidence; b: infestation intensity of infested host specimens; $c$ : infestation intensity of infested host specimens by rare parasites; $d$ : numbers of parasite species per host $(S)$ and evenness (J). Abbreviations denoting rare parasites: A.s. = Anisakis simplex, C.s. = Contracaecum sp., D. v. = Derogenes varicus, E.g. = Echinorhynchus gadi, P.l. = Pomphorhynchus laevis, S.s. = Schistocephalus sp. 

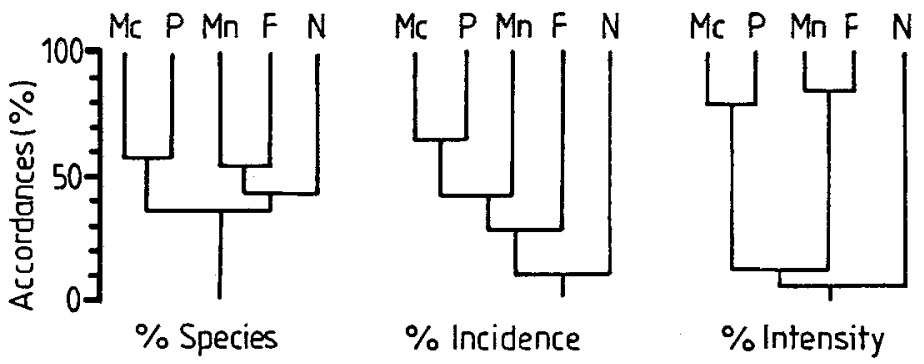

Fig. 13. Relationships of five goby hosts by means of the Renkonen index, regarding numbers, incidence and intensity of joint parasite species. Gobies: $\mathrm{Mc}=P$. microps, $\mathrm{P}=P$. pictus, $\mathrm{Mn}=$ $P$. minutus, $\mathrm{F}=$ Gobiusculus flavescens, $\mathrm{N}=$ Gobius niger

Pomphorhynchus laevis and Echinorhynchus gadi in the rectum, whereas Corynosoma sp. builds up cysts on the outer wall of the rectum. Anisakis simplex and Contracaecum sp. settle in the body cavity, mostly on the liver, whereas Schistocephalus sp. fills out this space almost completely. The parasite may reach one third of the weight of its host. Among the four most abundant parasites, $P$. atomon prefers the midgut but is sometimes found also in the stomach of $P$. minutus and $G$. flavescens (Fig. 14). A greater microhabitat spectrum is displayed by Hysterothylacium sp. which is mostly found in the midgut but also in stomach, rectum and, in G. niger, in the body cavity (Fig. 14). Whereas in $P$. microps, $C$. concavum infests exclusively the kidney, in $P$. pictus and $G$. flavescens it is found on fins and skin as black spots; only also few penetrate the kidney of $P$. pictus (Fig. 14). C. lingua seems to prefer the pectoral fins of $G$. niger (Fig. 14).

The affinity index describes the probability of the existence of several parasites in a host specimen (Table 3). Not only species with high abundances, such as Hysterothylacium and $P$. atomon, but also the less abundant Bothriocephalus, present high affinities

Table 2. Specificity indices of 13 helminth parasites and of the total parasite community of 5 goby species from Dahmeshöved, regarding intensities (SI-I) and incidences (SI-E)

\begin{tabular}{|lllc|}
\hline Species & SI-I & SI-E & (SI-I + SI-E):2 \\
\hline Bothriocephalus scorpii & 0.67 & 0.66 & 0.67 \\
Schistocephalus sp. & 0.68 & 0.71 & 0.70 \\
Derogenes varicus & 0.83 & 0.88 & 0.85 \\
Podocotyle atomon & 0.80 & 0.67 & 0.74 \\
Cryptocotyle concavum & 0.75 & 0.77 & 0.76 \\
Cryptocotyle lingua & 1 & 1 & 1 \\
Hysterothylacium sp. & 0.94 & 0.76 & 0.85 \\
Anisakis simplex & 0.73 & 0.76 & 0.74 \\
Contracaecum sp. & 0.90 & 0.92 & 0.91 \\
Echinorhynchus gadi & 0.77 & 0.76 & 0.77 \\
Pomphorhynchus laevis & 0.86 & 0.87 & 0.87 \\
Neoechinorhynchus rutili & 1 & 1 & 1 \\
Corynosoma sp. & 1 & 1 & 0.84 \\
Community index (SIC) & 0.84 & 0.83 & \\
\hline
\end{tabular}




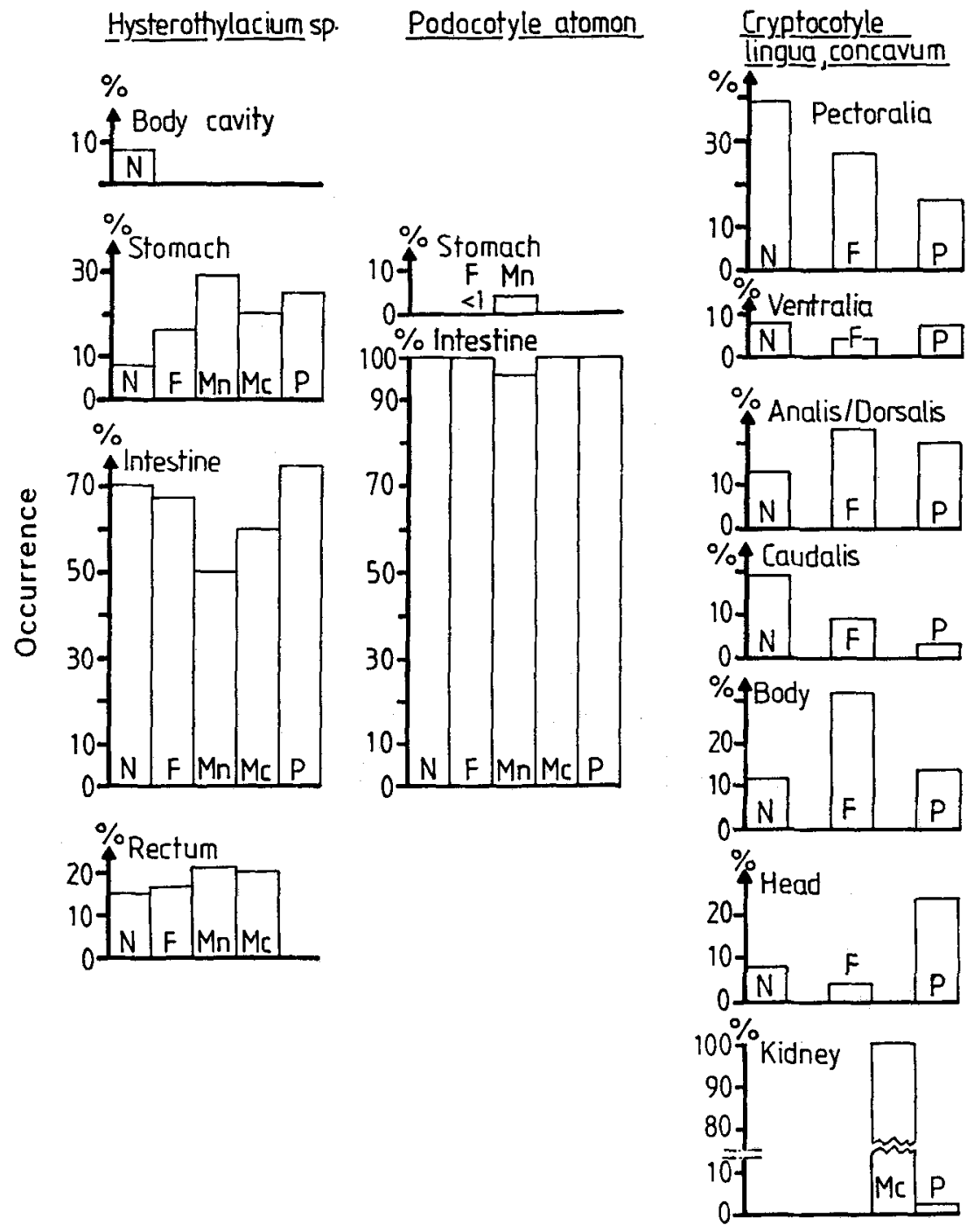

Fig. 14. Preferred microhabitats of four frequent parasites in five goby hosts: $\mathrm{N}=G$. niger, $\mathrm{F}=$ $G$. flavescens, $\mathrm{Mn}=P$. minutus, $\mathrm{Mc}=P$. microps, $\mathrm{P}=P$. pictus

to other parasites-which means frequent associations. C. concavum reveals an intermediate position because it appears in masses but in only three of five hosts. The same is true for P. laevis and E. gadi, whereas all other parasite species show low affinities (Table 3).

\section{Infestation of invertebrate intermediate hosts}

Figure 15a presents the abundance of planktonic copepods in Dahmeshöved during 1990. Two maxima, one in spring and a very high one in autumn, are characteristic. The 
Table 3. Affinity indices (AI) of 12 helminth parasites found in five goby species and of the total goby guild (AIG) in Dahmeshöved

\begin{tabular}{|c|c|c|c|c|c|c|}
\hline \multirow[t]{2}{*}{ Parasite species } & \multicolumn{5}{|c|}{ Host species } & \multirow[b]{2}{*}{ AIG } \\
\hline & P. $\min$ & P. mic. & P. pic. & G. flav. & G. nig. & \\
\hline Bothriocephalus scorpii & 0.19 & & 0.22 & 0.30 & 0.17 & 0.18 \\
\hline Schistocephalus sp. & 0.08 & & & 0.05 & 0.12 & 0.05 \\
\hline Derogenes varicus & 0.07 & & & 0.14 & & 0.04 \\
\hline Podocotyle atomon & 0.19 & 0.14 & 0.26 & 0.19 & 0.15 & 0.19 \\
\hline Cryptocotyle concavum & & 0.14 & 0.37 & 0.13 & & 0.13 \\
\hline Cryptocotyle lingua & & & & & 0.18 & 0.04 \\
\hline Hysterothylacium sp. & 0.19 & 0.22 & 0.34 & 0.17 & 0.25 & 0.23 \\
\hline Anisakis simplex & & 0.17 & & & & 0.03 \\
\hline Contracaecum sp. & 0.10 & & & 0.22 & & 0.06 \\
\hline Echinorhynchus gadi & 0.05 & 0.14 & & & 0.24 & 0.09 \\
\hline Pomphorhynchus laevis & & 0.17 & & & 0.22 & 0.08 \\
\hline Corynosoma sp. & & & & & 0.24 & 0.05 \\
\hline
\end{tabular}

maximal infestation with cestode larvae, which were lacking in the beginning and the middle of the year, followed the peaks of their hosts (Fig. 15b). The copepod guild, comprising 7 calanoids and the cyclopoid Oithona similis, revealed a varying composition during the course of 1990: Arcatia bifilosa was most abundant during times of low densities but $O$. similis at times after the maxima; Eurytemora hirundoides prevailed at the beginning and end of 1990 (Strohbach, 1991). Highest infestation ratios were found at times of low copepod abundance (Fig. 15b). Procercoids of cestodes, but also nematode larvae, were the most frequent parasite stages observed, whereas oncospheres predominantly occurred before and after the periods of copepod dominance (Fig. 15b).

$A$. bifilosa and $E$. hirundoides which were present at a rate of $14-15 \%$ during the year harboured the most parasites (Fig. 16). Arcatia discaudata and Paracalanus parvus were also relatively highly infested with cestode larvae, as was Centropages hamatus with nematodes. $O$. similis displayed the lowest infestation rate, though its ratio within the copepod guild was $57 \%$ (Fig. 16).

Benthic crustaceans were investigated between May and November 1990 in order to find larval stages of digeneans, acanthocephalans and nematodes (Fig. 18). Some of the parasites common in snails were also discovered in gammarids as metacercariae: Podocotyle atomon and probably Microphallidae; additionally, Hysterothylacium sp. larvae and acanthellae are found. The isopod Jaera also harbours Hysterothylacium sp. in its body cavity (Fig. 18b, d).

Snails were investigated between August and November 1990. The density of Littorina saxatilis presented a maximum in autumn, when 55 specimens per square meter were counted (Fig. 17a). The infestation incidence changed only slightly due to increasing infestation by shell-destroying Polydora ciliata, whereas the ratio of digeneans decreased in autumn (Fig. 17b); Cryptocotyle lingua vanished at the end of the investigation time. The abundance of the mud snails, Hydrobia spp. which were dominated by Hydrobia ulvae, was highest in late summer and decreased thereafter (Fig. 17c). Thus incidences and intensities of digenean sporocysts and rediae decreased in autumn after 


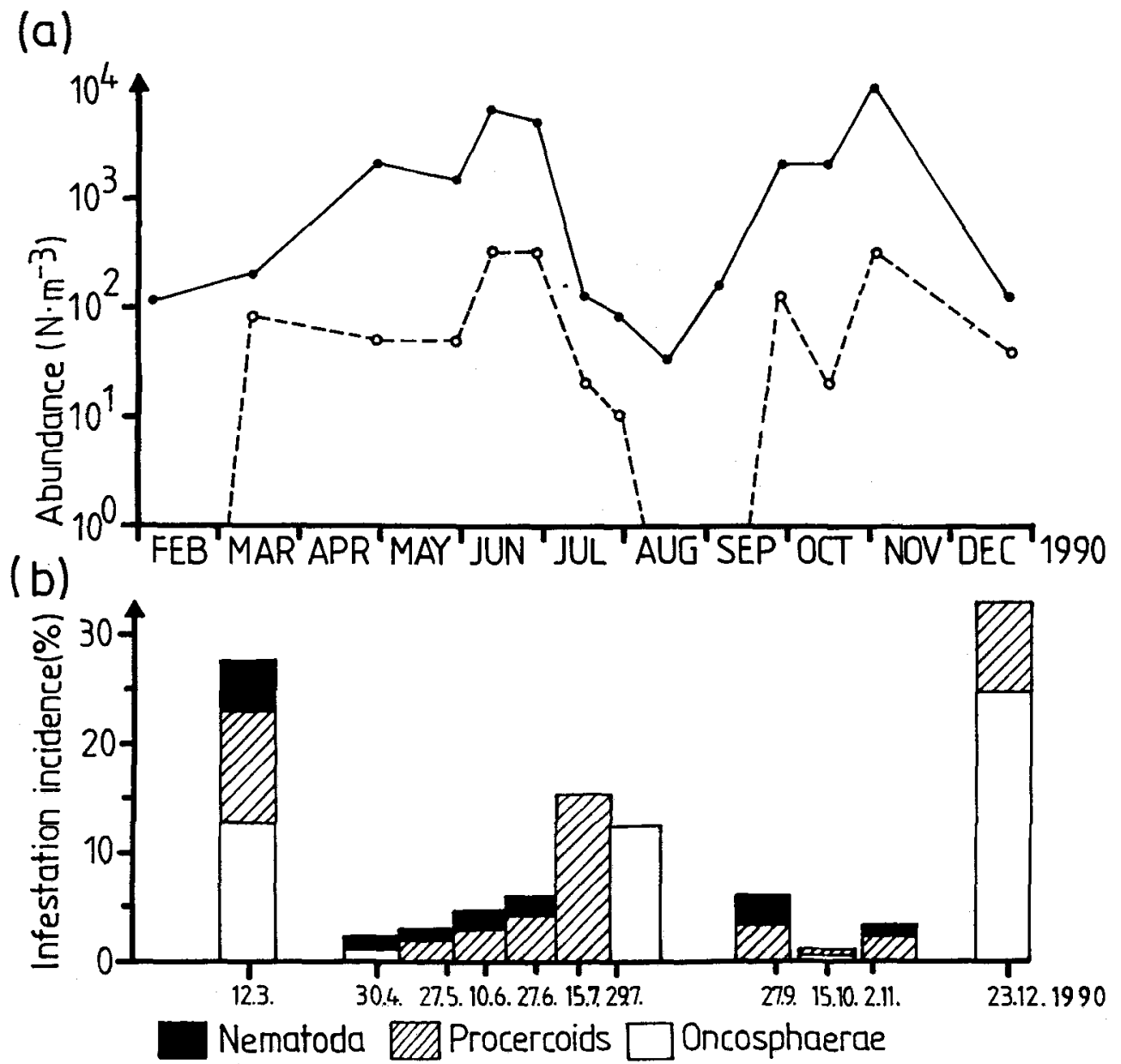

Fig. 15. Seasonality of planktonic copepods and their parasites from Dahmeshöved during 1990. a: abundances $\left(\mathrm{N} \mathrm{m}^{-3}\right)$ of all (solid line) and infested (broken line) copepods. b: Prevalences (\%) of cestode and nematode larvae

being maximal in late summer (Fig. 17d). Cryptocotyle concavum prevailed in mud snails, whereas Maritrema syntomocyclus and Himasthla sp. II were less conspicuous.

The density and infestation density of gammarids of $18000 \mathrm{~m}^{-2}$ and $5000 \mathrm{~m}^{-2}$, respectively, were extremely high; these values were clearly lower in Jaera albifrons (Fig. 18a, c). Regarding gammarids, $P$. atomon was the dominant parasite in spring, Hysterothylacium sp. in summer, and thereafter the Microphallidae with a maximal incidence of $25 \%$ in November (Fig. 18b). Acanthella larvae also occur in late summer, reaching maximal values in October. Hysterothylacium sp. is the only helminth parasite found in $J$. albifrons, where it attains higher rates of infestation than in gammarids, in summer (Fig. 18d). 


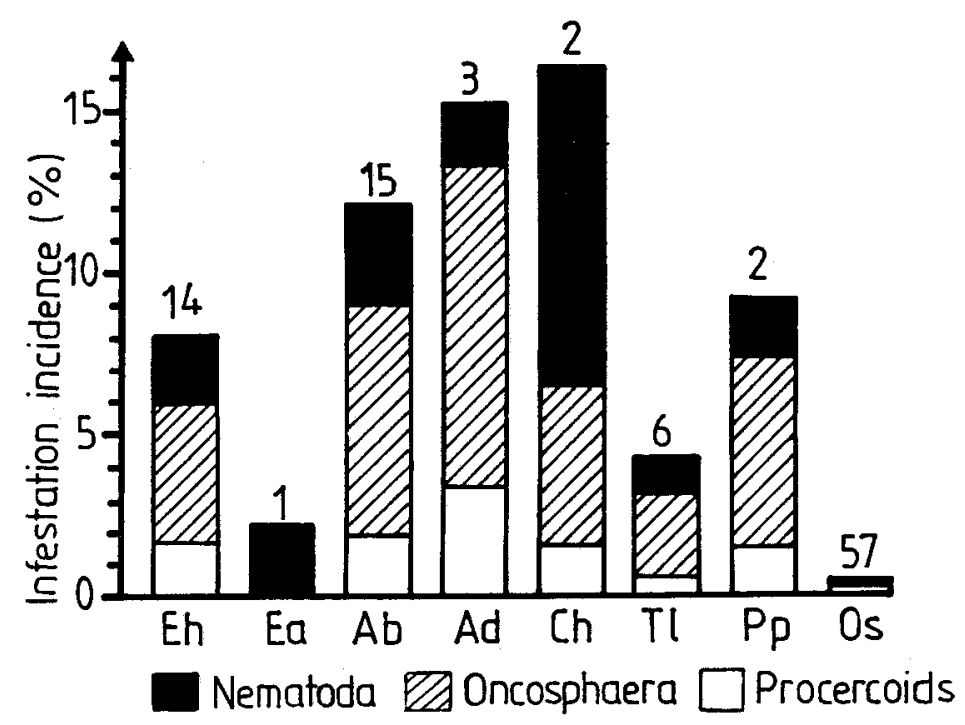

Fig. 16. Infestation incidence of helminth larvae in 8 copepod species from the plankton samples of 1990 in Dahmeshöved. The numbers above the columns mean the parts of the respective species within the copepod guild: $\mathrm{Ab}=$ Acartia bifilosa, $\mathrm{Ad}=A$. discaudata, $\mathrm{Ch}=$ Centropages hamatus, Ea $=$ Eurytomora affinis, $\mathrm{Eh}=E$. hirundoides, $\mathrm{Os}=$ Oithona similis, $\mathrm{Pp}=$ Paracalanus parvus, $\mathrm{Tl}=$ Temora longicornis

\section{Prey of gobies}

The prey spectrum of Pomatoschistus minutus comprised 25 components, 13 of which occurred in all four years of investigation (Fig. 19). With regard to the frequency of occurrence, gammarids prevailed in all years whereas other components such as harpacticoids, Mytilus or polychaetes were preyed on, at the most, by $10 \%$ of the sand gobies.

Gammarids dominated also in Pomatoschistus microps whose prey was completed by Mytilus, harpacticoids or isopods, the frequencies of which amounted to approx. $30 \%$ (Fig. 20). Gammarids and also some planktonic components such as calanoid copepods and cypris larvae are also preferred by Pomatoschistus pictus (Fig. 20). Of lesser frequencies are harpacticoids, Jaera or the suprabenthic Mysidacea.

Gammarids, calanoids and cypris-larvae were also of greatest importance in Gobiusculus flavescens (Fig. 20). Whereas gammarids attained $70 \%$ and calanoids $50 \%$ in 1989 , the latter component was preyed on by $90 \%$ G. flavescens in 1990 , when $70 \%$ gobies ingested gammarids or cypris larvae. Hunting of suprabenthic mysids is probably of lesser success in G. flavescens than in P. pictus (Fig. 20).

As Gobius niger has been sampled since 1983, the values of several years have been combined in two groups and compared with those of 1990 (Fig. 21). The prevailing components are gammarids of all three time groups. Jaera, Idotea, polychaetes, and Mytilus attained high, but changing, frequencies. This was also true for Corophium in 1990 (Fig. 21).

The prey of the respective goby species can be related to the way of life of the fish. 

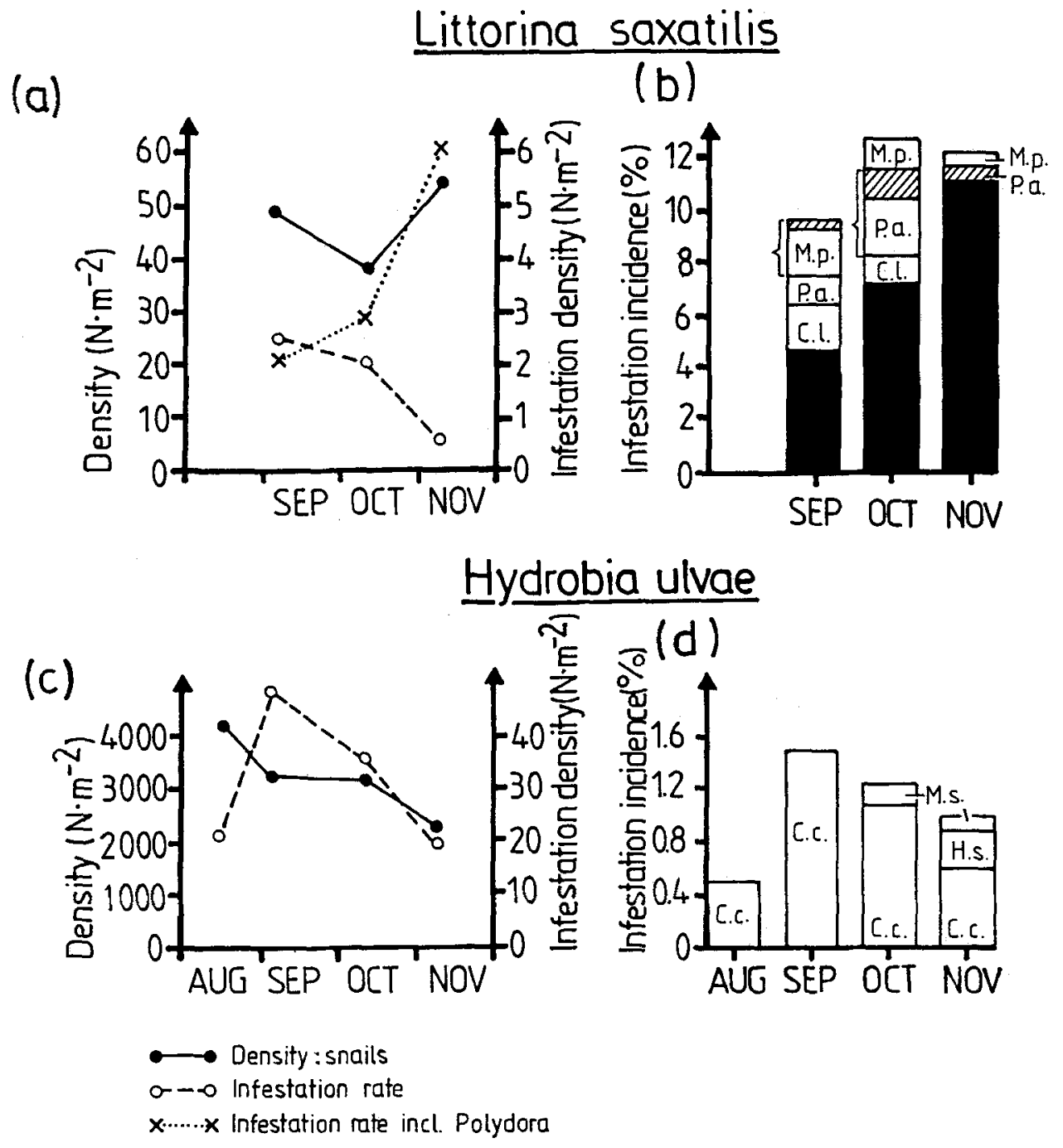

Fig. 17. Densities $\left(\mathrm{N} \mathrm{m}^{-2}\right)$, infestation densities $\left(\mathrm{N} \mathrm{m}^{-2}\right)$ and prevalences (\%) of Littorina saxatilis and Hydrobia ulvae from Dahmeshöved during late summer and autumn 1990. Black columns = Polydora ciliata, hatched boxes $=$ double infestation by $P$. ciliata and digeneans. Parasites: C.c. = Cryptocotyle concavum, C. $1 .=$ C. lingua, H.s. $=$ Cercaria himasthlinarum, M.p. $=$ Microphallus pygmaeus, M.s. = Maritrema sp. P.a. = Podocotyle atomon

Whereas $P$. minutus, $P$. microps and $G$. niger prefer benthic prey organisms, the appearance of gammarids in the suprabenthic $G$. flavescens results from a shortage of planktonic copepods in the summer months. P. pictus, however, is a benthic species which also hunts planktonic prey, by shooting very fast from the bottom into the free water column. 


\section{Gammarus spp.}
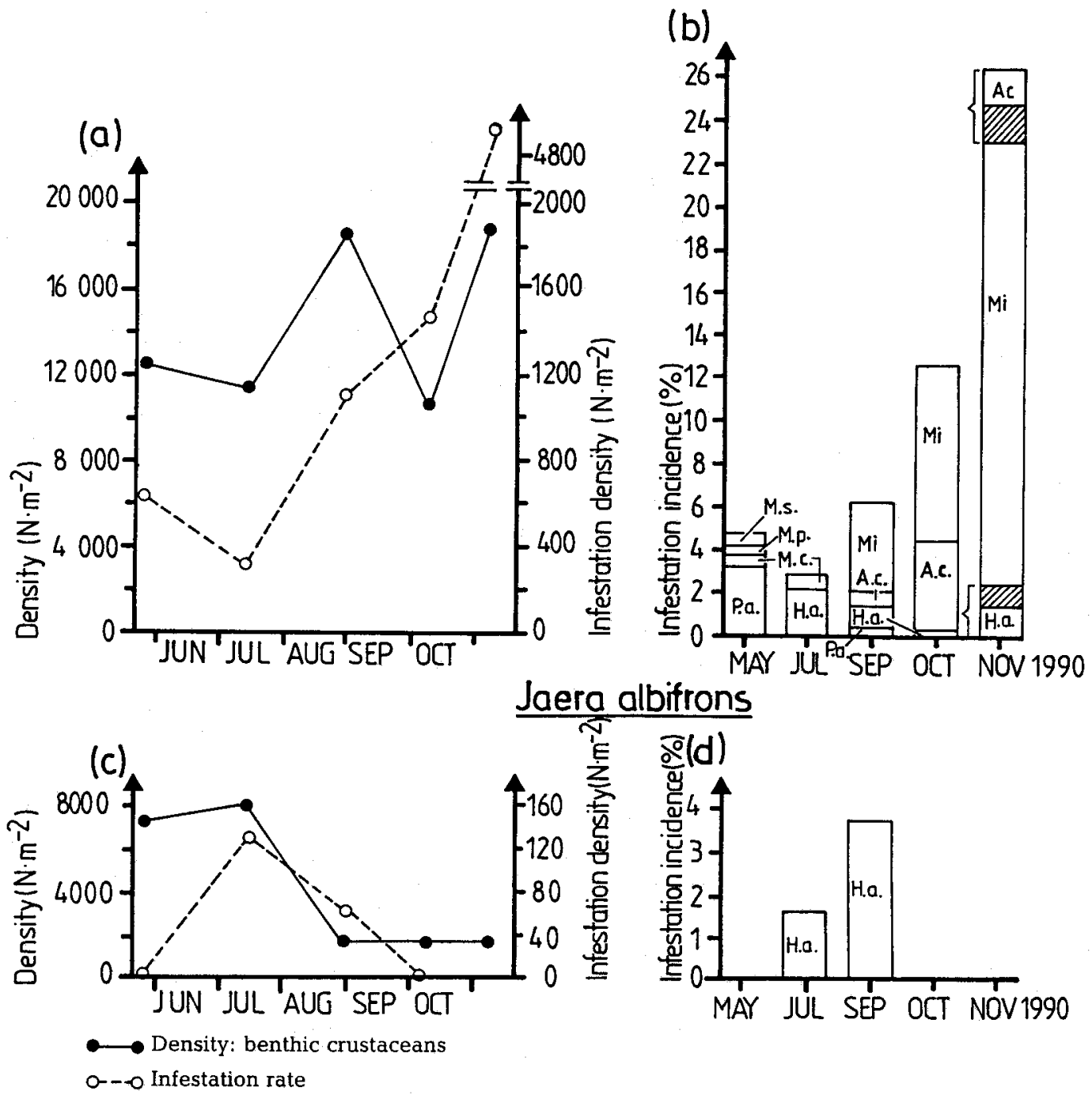

Fig. 18. Densities $\left(\mathrm{N} \mathrm{m}^{-2}\right)$, infestation densities $\left(\mathrm{N} \mathrm{m}^{-2}\right)$ and prevalences (\%) of Gammarus spp. and Jaera albifrons during 1990. Hatched boxes = double infestation of Hysterothylacium sp. and Microphallidae. Other parasites: $\mathrm{Ac}=$ Acanthella larvae, H.a. $=$ Hysterothylacium sp., M.c. $=$ Microphallus papillorobustum, M.s. = Maritrema sp. $\mathrm{Mi}=$ diverse Microphallidae, P.a. $=$ Podocotyle atomon

\section{DISCUSSION}

\section{Structure of parasite community}

The present investigations on five goby species from the Lübeck Bight may give new insight into the parasite community structures. Only 13 helminth species were found, 

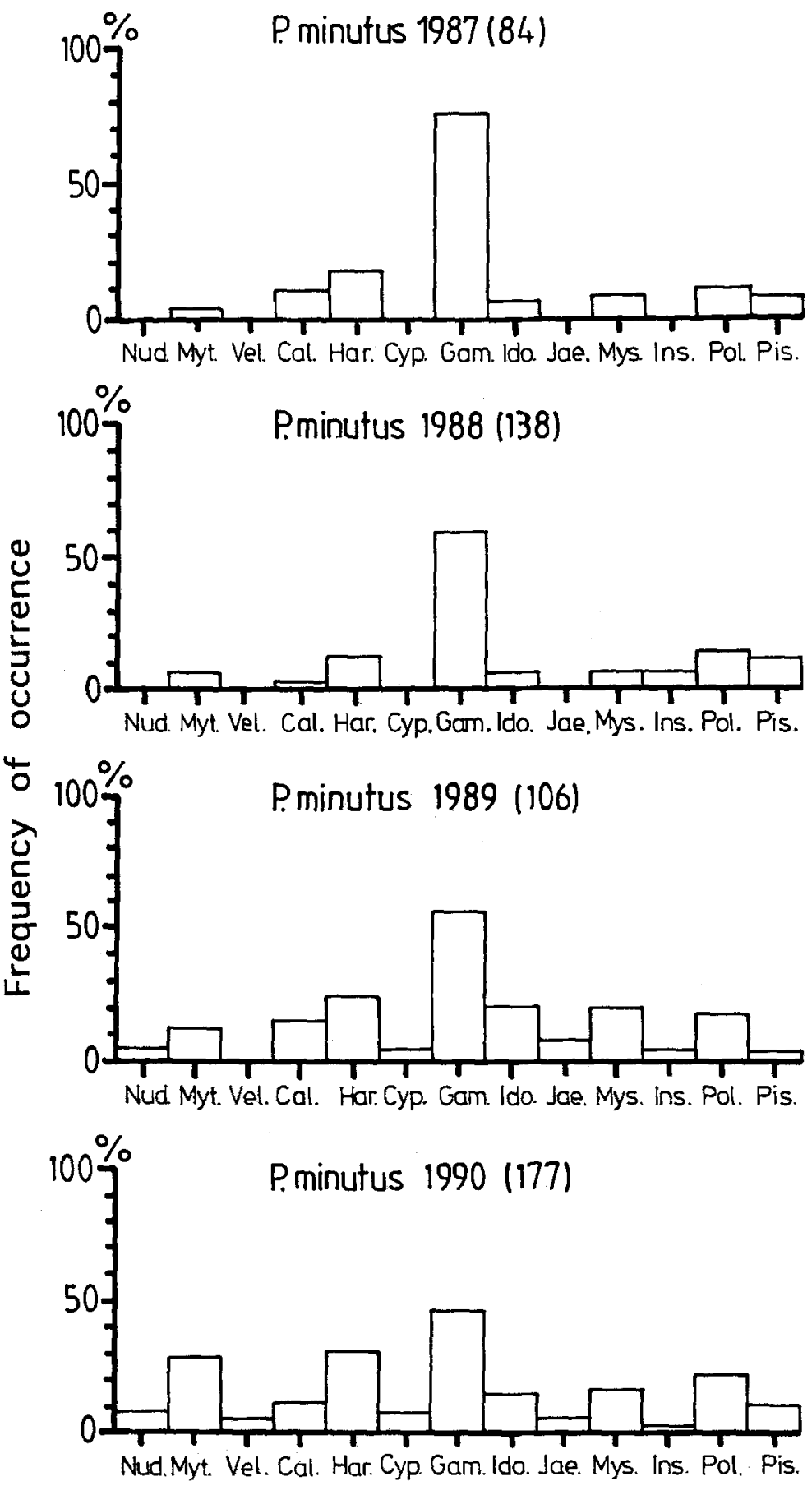

Fig. 19. Frequencies of occurrence of prey components ingested by $P$. minutus in 1987-90. In parentheses: numbers of investigated fish. Explanation of abbreviations in Fig. 21 

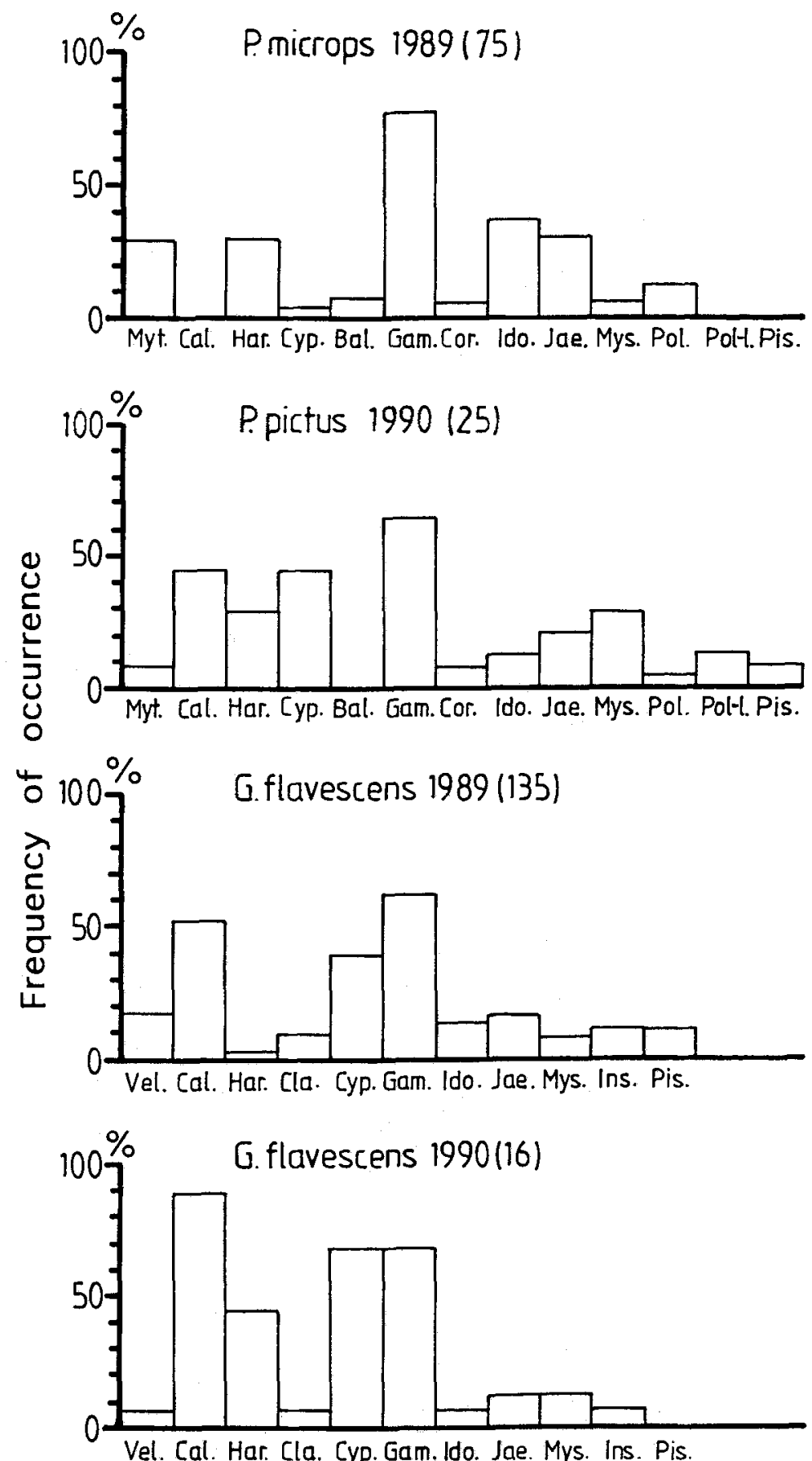

Fig. 20. Frequencies of occurrence of prey components ingested by $P$. microps and $G$. flavescens during 1989 and 1990. In parentheses: numbers of investigated fish. Explanation of abbreviations in Fig. 21 


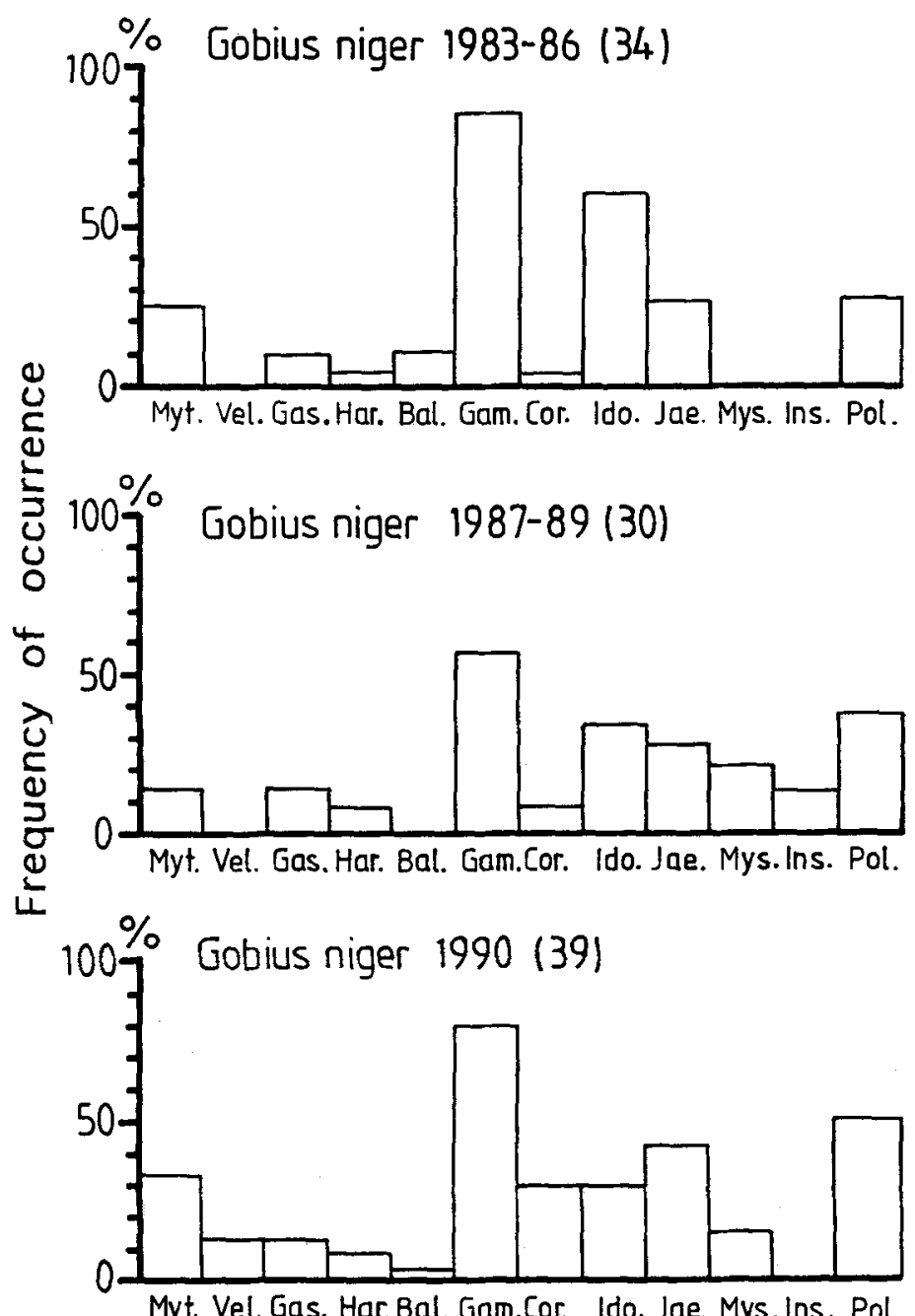

Fig. 21. Frequencies of occurrence of prey components ingested by G. niger during 1983-1990. In parentheses: number of investigated fish. Abbreviations: Bal, = Balanidae, Cal. = Calanoidea, Cla. $=$ Cladocera, Cor. $=$ Corophium, Cyp. = Cypris larvae, Gam. = Gammaridae, Gas. = Gastropoda, Har. $=$ Harpacticoidea, Ido. = Idotea, Ins. = Insecta, Jae. = Jaera, Mys. = Mysidacea, Myt. = Mytilus, Nud. $=$ Nudibranchia, Pis. = young fish, Pol. = Polychaeta, Pol-1. = Polychaeta larvae, Vel. = veliger larvae

which is apparently due to low salinities, a number which is lower than at marine sites (Möller-Buchner, 1987; Holmes, 1989) or limnetic habitats (Wootton, 1976; MöllerBuchner, 1987). Thus, these results follow the brackish water rules of species minimum (Remane, 1958). Only 8 helminth parasites were found in the eelpout Zoarces viviparus from the Lübeck Bight, which comprises species identical to those found in this investigation (Zander, 1991). The goby host with the highest species burden (10) is Pomatoschistus minutus; the least species (5) were found in Pomatoschistus pictus. However, when 
incidences are regarded, $P$. minutus clearly differs from the other gobies with a mean of only $40 \%$ and with the lowest individual and species burden. Diversity being high, a balanced composition of parasite species can be assumed in the sand goby. In contrast, the other goby hosts reveal a higher incidence of infestation, higher species and especially individual burdens, combined with lower diversities.

The metacommunities (Esch et al., 1988) are in part similar (Pomatoschistus microps/ $P$. pictus, $P$. minutus/Gobiusculus flavescens) but in part, of very low conformity (Gobius niger/all other hosts, $P$. microps/P. minutus). $P$. pictus may have relations to the $P$. minutus/G. flavescens group which is probably due to the respective kind of prey foraging. G. flavescens lives suprabenthically; at a size of $30 \mathrm{~mm}, P$. minutus changes its life style to a benthic way of life (Zander \& Hagemann, 1986, 1987) and is therefore exposed to cestode bearing copepods over longer periods of time than $P$. microps or G. niger (Zander, 1979).

The high rates of specificity of some parasites must be related to the reduced host species number as displayed by the goby guild from Lübeck Bight. Neoechinorhynchus rutili attains the maximum value of 1 in $P$. minutus, but is a euryhaline fresh-water parasite (Bykhovskii, 1964) found also in the Schlei fjord, which has a clear salinity gradient (Zander \& Westphal, 1991). It is probably transported from fresh or low brackish water into the Lübeck Bight. Corynosoma sp., the specifity index of which is 1 in G. niger, may exist only in longer living hosts as it is found also in the eelpout of the Lübeck Bight (Zander, 1991). The third parasite species with an index of 1 is Cryptocotyle lingua, which should live on pelagic fish hosts (Sindermann \& Farrin, 1962) and not on epibenthic ones like G. niger. In contrast to $P$. minutus from Lübeck Bight, $P$. minutus of the Schlei fjord was not infested by this digenean, whereas $P$. microps was, to a low degree $(\mathrm{Kreft}, 1991$ ).

An important factor governing parasite settlement is the dependence of each kind of prey on the respective habitat as well as on the life span of the host. Additionally, the rivalry or affinity between parasite species, evaluated here with a new index, also influences the infestation ratios. Hysterothylacium sp. and Podocotyle atomon, both of which display a widespread occurrence as well as high intensities, reveal great affinities as does Bothriocephalus scorpii which occurs in very low abundances. The parasite supracommunity (Esch et al., 1988) of the 5 gobies from the Lübeck Bight may, therefore, be ranged in the middle of the scale between isolation and interaction (Holmes \& Price, 1980, see below). The selection of different microhabitats by Cryptocotyle concavum or C. lingua depends presumably to a lesser degree on competition with other parasite species than on coevolution with their respective hosts. This is particularly demonstrated by $C$. concavum which settles in the skin of most of its hosts, but in the kidney of P. microps (Zander et al., 1984; Kreft, 1991; Zander \& Westphal, 1991).

The structure ot a parasite community is strongly influenced by the ratios of satellite, secondary and core species (Hanski, 1982; Holmes, 1989). Holmes (1991) proposed to separate these groups at the 40 or $60 \%$ level, respectively, and claimed a positive correlation between infestation incidence and mean intensity. This correlation is given in the Lübeck Bight community with a significance of 0.001 (Fig. 22). Regarding the traditional classification of dominance, $5(=8 \%)$ of 65 parasite-host combinations are eudominant and $3(=5 \%$ ) are dominant (Fig. 23a). According to Holmes (1991), only Hysterothylacium sp. in G. niger and C. concavum in P. microps are core species ( $3 \%$ ); but 32 host-parasite combinations $(=42 \%$ ) have only a satellite status (Fig. $23 \mathrm{~b}$ ). 


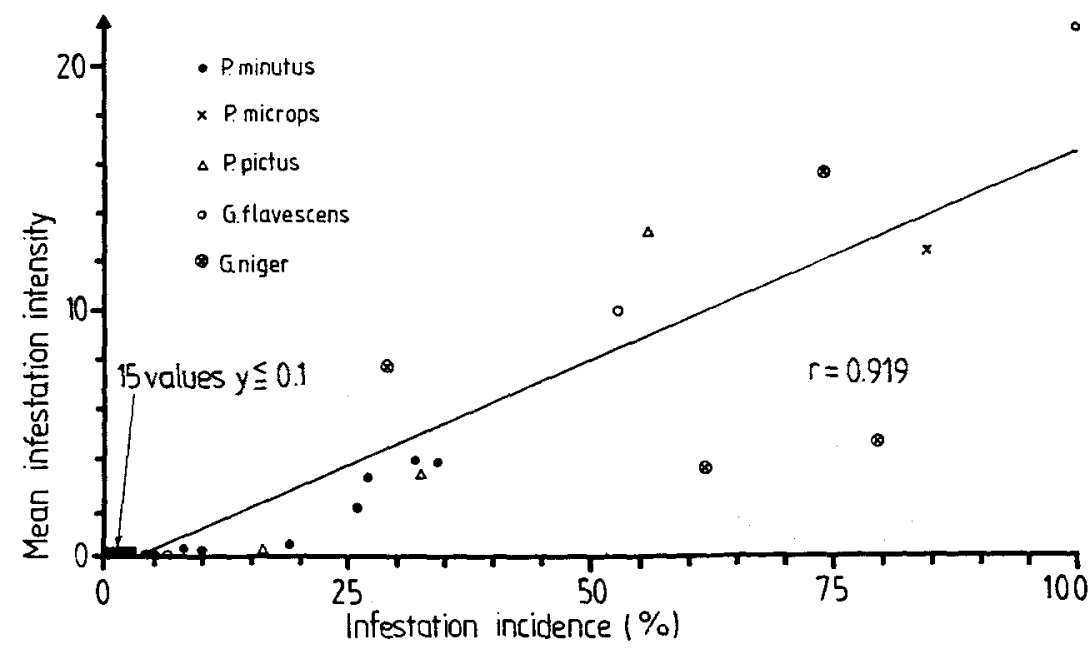

Fig. 22. Correlations of extensities (X-axis) and mean intensities ( $Y$-axis) of 36 goby-parasite relationships in Dahmeshöved during 1989/90

(a)
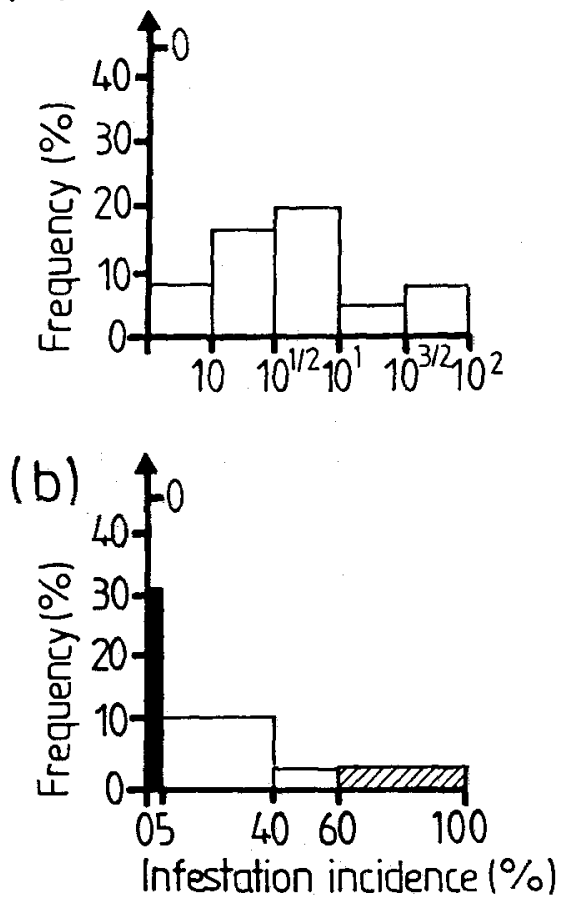

Fig. 23. Frequencies (\%) of 65 possible goby-parasite combinations arranged on the scale of the respective infestation incidences (\%). The zero mark on the Y-axes means the undetected gobyparasite systems in Dahmeshöved. a: rates of infestation subdivided on the basis of the dominance scale; $b$ : rates of infestation subdivided on the basis of the satellite-/core-species scale (Holmes, 
Bush \& Holmes (1986) found among water birds more specialists than generalists in the category of core species. In this investigation, the two types are equal in numbers. $C$. concavum displays a balanced parasite-host relationship in the kidneys of $P$. microps but not in $P$. pictus where it more frequently occurs on the skin, as found also in $P$. minutus from the Schlei fjord (Kreft, 1991). Hysterothylacium sp., a core species in $G$. niger but a secondary or satellite species in the other gobies, apparently needs longer living hosts to be accumulated, as was demonstrated earlier in eelpout $Z$. viviparus from the Lübeck Bight (Zander, 1991). In contrast, P. atomon, a core species in $Z$. viviparus, is only a satellite in $G$. niger. This disagreement can be solved by direct observations of gammarids bearing Podocotyle-cysts in $P$. minutus, $P$. microps and $G$. niger which often pass through the intestinal tracts without excysting. In $G$. flavescens, however, these metacercariae excyst in every observed case.

According to the investigation in the Schlei fjord, Neoechinorhynchus is a core species in Z. viviparus, a secondary species in Gasterosteus aculeatus, but a satellite species in P. minutus and P. microps (Zander \& Westphal, 1991).

\section{The dynamics of parasite community}

The clear seasonality of Podocotyle atomon is apparent because in springtime it especially infests Gobiusculus flavescens and Pomatoschistus minutus to a high degree. Similar results are also found by Kreft (1991) in Pomatoschistus microps or Gasterosteus aculeatus in the Schlei fjord where this parasite reveals maxima, not only in spring but also in autumn.

An autumnal maximum of $P$. atomon is not proved in the Lübeck Bight probably due to the population composition of juveniles only in the Pomatoschistus and Gobiusculus species and the invulnerability of Gobius niger to this parasite. However, Cryptocotyle concavum attains autumnal maxima in the Lübeck Bight as well as in the Schlei fjord but at the latter site with much higher numbers of parasites (Kreft, 1991).

All the other parasites found in the Lübeck Bight show no clear seasonalities. A maximum of species burden occurs in summer, followed by a decrease in parasite species richness. This may be caused by the death of adult gobies as well as by the low infestation ratios of young gobies. This assumption is supported by the increasing number of parasites in the larger size classes of $P$. minutus and $G$. niger, the largest species of the goby guild. Pioneer parasite species, such as Bothriocephalus scorpii, are also present in older gobies whereas Hysterothylacium sp. decreases in number in larger $P$. minutus and $P$. microps. The same trend is found in G. niger and G. flavescens which are infested as juveniles by $P$. atomon. Identical results were attained by Kreft (1991) on $P$. atomon in gobies and sticklebacks of the Schlei fjord. G. niger is able to accumulate Hysterothylacium sp. during its whole life span. This is also true of $G$. aculeatus of the Elbe and Eider rivers (Möller-Buchner, 1987). A similar, extreme accumulation, which may influence the health situation of the hosts has been described in Zoarces viviparus from the Lübeck Bight (Zander, 1991). In cases where the younger fish are more severely infested than the adults, one may assume direct or indirect mortality, as is found in sticklebacks which are more easily caught by predators when they bear parasites (Milinski, 1985). It is assumed that Gasterosteus aculeatus with dermal cysts of $C$. concavum have a shorter life span 
than uninfested specimens of the same age group (Zander et al., 1984; Kreft, 1991).

Thus, fluctuations in the parasite communities observed in the five gobies of the Lübeck Bight may express the special adaptations of the respective host species.

\section{Life cycles}

It was not possible in every case to trace the total life cycle of goby parasites in the Lübeck Bight. Thus, early life stages of nematodes, acanthocephalans and cestodes can only be roughly determined. In contrast to digeneans, the first intermediate hosts of other parasites are not species-specific but, at the most, group-specific: Cestoda live in planktonic copepods; acanthocephalans and nematodes in benthic peracarids; nematodes, sometimes also in planktonic copepods. Regarding Podocotyle atomon, the results on this species in the Lübeck Bight are identical with those on the same species in the Schlei fjord where it infests, among peracarids, mostly Idotea chelipes (Kreft, 1991).

The first intermediate hosts of digeneans in the Lübeck Bight are Littorina saxatilis for P. atomon and Cryptocotyle lingua; Hydrobia ulvae for Cryptocotyle concavum. These host specifities may differ from area to area, because $C$. lingua in the Schlei fjord preferably infests Littorina littorea, whereas $C$. concavum is found there in Hydrobia ventrosa and $H$. neglecta (Zander et al., 1984; Kreft, 1991).

The gobies themselves are second intermediate hosts to Cryptocotyle spp., cestodes, nematodes and Corynosoma sp. in the Lübeck Bight. Only the cercariae of Cryptocotyle spp. penetrate into their hosts actively, whereas all other parasites are transmitted by the

Table 4. Evaluation of the parasite community of five goby hosts from Dahmeshöved by means of four parameters: I. Auto-/allogeny; steps $-0=$ autogenic, goby is final host; $0.5=$ autogenic, goby is intermediate host; $1=$ allogenic. II. Affinities to other parasites; $0=$ affinity index (AI) is greater than $0.1 ; 0.5=\mathrm{AI}$ is between 0.06 and $0.10 ; 1=\mathrm{AI}$ is smaller than 0.06 . III. Infestation incidence; $0=$ satellite species; $0.5=$ secondary species; $1=$ core species. IV. Specializations; $0=$ one goby species is infested; $0.5=2-3$ goby species are infested; $1=4-5$ goby species are infested

\begin{tabular}{|lllllll|}
\hline \multicolumn{7}{c}{ Category } \\
Parasite species & I & II & IIl & IV & Sum & Mean \\
\hline Bothriocephalus scorpii & 0.5 & 0 & 0 & 1 & 1.5 & 0.4 \\
Schistocephalus sp. & 1 & 1 & 0 & 0.5 & 2.5 & 0.6 \\
Derogenes varicus & 0 & 1 & 0 & 0.5 & 1.5 & 0.4 \\
Podocotyle atomon & 0 & 0 & 0.5 & 1 & 1.5 & 0.4 \\
Cryptocotyle concavum & 1 & 0 & 1 & 0.5 & 2.5 & 0.6 \\
Cryptocotyle lingua & 1 & 1 & 0.5 & 0.5 & 3.0 & 0.8 \\
Hysterothylacium sp. & 0.5 & 0 & 1 & 1 & 2.5 & 0.6 \\
Anisakis simplex & 1 & 1 & 0 & 0.5 & 2.5 & 0.6 \\
Contracaecum sp. & 1 & 0.5 & 0 & 0.5 & 2.0 & 0.5 \\
Echinorhynchus gadi & 0 & 0.5 & 0 & 0.5 & 1.0 & 0.3 \\
Pomphorhynchus laevis & 0 & 0.5 & 0 & 0.5 & 1.0 & 0.3 \\
Neoechinorhynchus rutili & 0 & 1 & 0 & 0 & 1.0 & 0.3 \\
Corynosoma sp. & 1 & 1 & 0 & 0 & 2.0 & 0.5 \\
Sum & 7.0 & 7.5 & 3.0 & 7.0 & & 6.2 \\
Parasite community & 0.54 & 0.58 & 0.23 & 0.54 & & 0.48 \\
\hline
\end{tabular}


prey organisms of the fish (Zander et al., 1984; Zander \& Döring, 1989; Kreft, 1991; Zander, 1991; Zander \& Westphal, 1991). On the other hand, gobies are natural prey for larger fish, sea birds and seals. Therefore, their additional role in the food web is that of transmitters of parasites to the final hosts (Zander, 1988; Zander \& Döring, 1989). Bothriocephalus scorpii and Hysterothylacium sp, are in this way transferred to predatory fish species (Möller \& Anders, 1986). Presumably, Hysterothylacium sp. is able to mature in the larger and longer living Gobius niger. This is also true for this nematode in Zoarces viviparus from the Lübeck Bight (Zander, 1991). All other parasites found in gobies are adapted to homoiothermic final hosts, mostly sea birds. Only Anisakis simplex and Contracaecum sp. are frequently found in seals (Reijnders et al., 1981), and Corynosoma sp. in cormorants (Reimer, 1969) and seals (Helle \& Valtonen, 1981). Therefore, only 3 of the 13 parasites of gobies from the Lübeck Bight are allogenic species, in the sense of Esch et al. (1988), which means that they display at least a periodic absence from the aquatic habitat.

The gobies are final hosts for 2 Digenea and 3 Acanthocephala species. These are also transmitted by crustaceans which are the main food of the gobies (Zander \& Döring, 1989; Zander 1990). They present a rich resource of Podocotyle atomon, several acanthocephalans and Hysterothylacium sp. for gobies, as well as Microphallidae for birds. As Contracaecum larvae have been recognized in some Gammarus specimens, the way gobies are infested is clear now. Additionally, the succession of $P$. atomon, Hysterothylacium sp. and acanthocephalans, at first in crustaceans and thereafter in gobies, reveals the season-dependent life cycles of these parasites.

\section{Characterization of the Lübeck Bight by means of the parasite community}

The Baltic Sea is for the greatest part a brackish sea in which the organisms are adapted to low salinities. Its community has attained a stable status though only a few organismic interactions have developed (Remmert, 1989). The low salinity has also the effect of a filter on parasites (Kennedy, 1991) which is intensified when more than one host is involved in the life cycles. Therefore, the Lübeck Bight which is characterized by salinities of $8-12 \%$ influences the macrohabitats of a parasite more decisively than the microhabitats (in the sense of Rohde, 1982). This implies that only few specializations can be expected such as, for example, the microhabitat of Cryptocotyle concavum in the kidney of its second intermediate host Pomatoschistus microps. This parasite-host relationship is considered to be a progressive coevolution in the brackish milieu (Zander et al., 1984). All other goby-helminth interactions of the Lubeck Bight may be founded on "host capture" (Holmes \& Price, 1980), as intermediate hosts bearing parasite larvae are the common prey of these fish, especially Gammarus spp. with metacercariae of Podocotyle atomon. According to former investigations, Gammarus specimens were not infested until they reached a length of $9 \mathrm{~mm}$ (Zander \& Döring, 1989). In this investigation, however, $5 \mathrm{~mm}$-large specimens were found with cysts of this digenean, this size being preferred as prey by Pomatoschistus minutus (Zander, 1990). Additionally, small Gammarus spp. harbour a rich association of diverse helminth larvae, which also cause the transmission of nematodes and acanthocephalans (Zander \& Döring, 1989; Zander, 1991).

Using the island theory (MacArthur \& Wilson, 1967), Holmes \& Price (1980) compare the colonization of hosts by parasites with the colonizing of islands by invaders. Accord- 
ing to Holmes \& Price (l.c.), the number of microhabitats offered by the hosts corresponds to the size of the island, and the difficulties surrounding parasite settlement such as, for example, immune defense of the host, correspond to the distance of the islands from the continent (Esch et al., 1988). The resulting coevolution of parasite and host may be a point of equilibrium such as in the island theory when newly invading parasites can only replace others that die out because all the existing niches are densely packed. This point of equilibrium has not yet been reached by parasites of the Baltic Sea, although some coevolutive developments can be recognized: some parasites prefer distinct microhabitats; single infestation occurs instead of mass infestation in some cestodes and acanthocephalans; and tolerance of different parasite species begins to develop.

The present results from the Lübeck Bight differ from those on some sea fishes (Holmes, 1989, 1991) or some freshwater fishes (Kennedy, 1989, 1991) in comprising more microhabitats than only that of the intestinal tract. Additionally, these investigations focussed on brackish water where parasite communities are only scantly known. Table 4 tries to use numerically the single parameters discussed above for a characterization of the parasite community of the Lübeck Bight. As a result, a value in the middle of the interactive scale (Holmes \& Price, 1980) is attained. This may emphasize the thesis of Remmert (1989) who calls the Baltic Sea a balanced ecosystem. The utilizability of the regarded criteria must be proved in the future, especially with regard to brackish habitats. This calculation goes even further than the results of Möller-Buchner (1987), which are based on the diversities of the parasite communities of sticklebacks studied in order to analyse the quality of the Elbe and Eider rivers.

Acknowledgements. H. Blessin, R. Fiedler, B. Janßen, Dr. D. Keyser, R. Kock and C. Schmidt supported us during the diving operations and helped to catch the fishes. J. Melander kindly offered his plankton samples of the year 1990 for our copepod investigations. M. Hänel drew all the figures. C. Berger improved the English text. Many thanks to all of them as well as to the colleagues of the Zoologisches Institut and Museum who took over the teaching duties of the first author in summer 1991. Finally, the University Hamburg supported the first author in winter $1990 / 91$ by providing funds from the "Forschungspool".

\section{LITERATURE CITED}

Arntz, W. E., 1974. Biomasse und Produktion des Makrobenthos in den tieferen Teilen der Kieler Bucht. - Kieler Meeresunters. 27, 36-72.

Behrens, G., 1985. Zur Nahrungswahl von Seehunden (Phoca vitulina, L. 1758) im Wattenmeer Schleswig-Holsteins. - Z. Jagdwiss. 31, 3-14.

Bush, A. O. \& Holmes, J. C., 1986. Intestinal helminths of lesser scaup ducks: patterns of association. - Can. J. Zool. 64, 131-141.

Bykhovskii, I. (Ed.) 1964. Key to parasites of freshwater fish of the USSR. Israel Program Scient. Translation, Jerusalem, 886 pp.

Doornbos, G., 1984. Piscivorous birds on the saline Lake Grevelingen, the Netherlands: abundance, prey selection and annual food consumption. - Neth. J. Sea Res. 18, 457-479.

Esch, G. W., Kennedy, C. R., Bush, A. O. \& Aho, J. M., 1988. Patterns in helminth communities in freshwater fish in Great Britain: alternative strategies for colonization. - Parasitology 96, $519-532$.

Evans, S., 1984. Energy budgets and predation impact of dominant epibenthic carnivores on a shallow soft bottom community at the Swedish west coast. - Estuar. coast. Shelf Sci., 18, 651-672. 
Fonds, M., 1973. Sand gobies in the Dutch Wadden Sea (Pomatoschistus, Gobiidae, Pisces). - Neth. J. Sea Res. $6,417-478$.

Hamerlynck, O, Vyver, P. van de \& Janssen, C. R., 1990. The trophic position of Pomatoschistus Iozanoi (Pisces: Gobiidae) in the Southern Bight. In: Trophic relationships in marine environments. Ed. by M. Barnes \& R. N. Gibson. Aberdeen Univ. Press, Aberdeen, 183-190.

Hanski, I., 1982. Dynamics of regional distribution: the core and satellite species hypothesis. - Oikos $38,210-221$.

Hartwig, E. \& Söhl, M., 1975. Zur Nahrung der Silbermöwe (Larus argentatus) auf der Nordseeinsel Sylt. II. Zusammensetzung der Nahrung. - Zool. Anz. 194, 350-360.

Helle, E. \& Valtonen, E. T., 1981. Comparison between spring and autumn infection by Corynosoma (Acanthocephala) in the ringed seal (Pusa hispida) in the Bothnian Bay of the Baltic Sea. Parasitology 82, 287-296.

Hesthagen, I. H., 1977. Migration, breeding and growth in Pomatoschistus minutus (Pallas) (Pisces, Gobiidae) in Oslofjorden, Norway. - Sarsia 63, 17-26.

Holmes, J. C., 1989. Helminth communities in marine fishes. In: Parasite communities: patterns and processes. Ed. by G. W. Esch, A. O. Bush \& J. M. Aho. Chapman \& Hall, London, 101-130.

Holmes, J. C., 1991. Spatial scale and important species in the analysis of communities of parasites. In: Second international school: Parasite host environment. Bulgarian Academy of Sciences, Sofia, 1-14.

Holmes, J. C. \& Price, P. W., 1980. Communities of parasites. In: Community ecology: Patterns and processes. Ed. by D. J. Anderson \& J. Kikkowa. Blackwell, Oxford, 187-213.

Kennedy, C. R., 1989. Helminth communities in freshwater fish: structured communities or stochastic assemblages. In: Parasite communities: patterns and processes. Ed. by G. W. Esch, A. O. Bush \& J. M. Aho. Chapman \& Hall, London, 131-156.

Kennedy, C. R., 1991. The role of interspecific competition in structuring helminth parasite communties. In: Second international school: Parasite host environment. Bulgarian Academy of Sciences, Sofia, 185-202.

Køie, M., 1979. On the morphology and life-history of Derogenes varicus (Müller, 1784) Looss, 1901 (Trematoda, Hemiuridae). - Z. ParasitKde. 59, 67-78.

Køie, M., 1983. Digenetic trematodes from Limanda limanda (L.) (Osteichthyes, Pleuronectidae) from Danish and adjacent waters, with special reference to their life-histories. - Ophelia 22 . $201-228$.

Kreft, K.-A., 1991. Befalls- und Populationsdynamik ausgewählter digener Trematoden und ihrer Wirte in der Schlei. Diss. Univ, Hamburg, $289 \mathrm{pp}$.

MacArthur, R. H. \& Wilson, E. O., 1967. The theory of island biogeography. Princeton University Press, Princeton, N. J., 203 pp.

Markowski, S., 1935. Die parasitischen Würmer von Gobius minutus Pall. des Polnischen Baltikums. - Bull. Acad. pol. Sci. (Cl. II, Ser. Sci. biol.) 2, 251-260.

Melander, J., 1989. Die Sukzession des Aufwuchs einer Mole in der Lübecker Bucht. Dipl.-Arb., Univ. Hamburg, $270 \mathrm{pp}$.

Milinksi, M., 1985. Risk of predation of parasitized sticklebacks (Gasterosteus acculeatus, L.) under competition for food. - Behaviour 93, 203-216.

Möller, H., 1975. Parasitological investigation on the European eelpout (Zoarces viviparus) in the Kiel-Fjord (Western Baltic). - Ber. dt. wiss. Kommn Meeresforsch. 24, 63-70.

Möller, H. \& Anders, K., 1986. Diseases and parasites of marine fishes. Möller, Kiel, 265 pp.

Möller-Buchner, J., 1987. Untersuchungen zur Parasitenfauna drei- und neunstachliger Stichlinge (Gasterosteus acculeatus und Pungitus pungitus) aus Elbe, Eider und Schlei. Diss. Univ. Hamburg, $230 \mathrm{pp}$.

Reijnders, P. J. H., Clausen, B., Haaften J. L. van \& Kamp, J. van der, 1983. Diseases and parasites in harbour seals of the Wadden Sea. In: Ecology of the Wadden Sea. Ed. by W. J. Wolff. Balkema, Rotterdam, 2(7), 33-38.

Reimer, L., 1969. Helminthen in Kormoranen von Brutkolonien der Deutschen Demokratischen Republik. - Wiss. Z. E.-M.-Arndt-Univ. Greifswald (Math.-naturw. R.) 18, 129-135.

Reimer, L., 1970. Digene Trematoden und Cestoden der Ostseefische als natürliche Fischmarken. Parasit. SchrReihe 20,1-144.

Remane, A., 1958. Die Biologie des Brackwassers. Binnengewässer 22, 1-348. 
Remmert, H., 1989. Ökologie. Springer, Berlin, 374 pp.

Rohde, K., 1982. Ecology of marine parasites. Univ. Queensland Press., St. Lucia, 245 pp.

Root, R., 1967. The niche exploitation pattern of the blue-gray gnatcatcher. - Ecol. Monogr. 37, $317-350$

Sievers, U., 1989. Nahrungsökologische Untersuchungen an Seehunden (Phoca vitulina, L. 1758) aus dem schleswig-holsteinischen Wattenmeer. - Zool. Anz. 222, 249-260.

Sindermann, C. J. \& Farrin, A. E., 1962. Ecological studies of Cryptocotyle lingua (Trematoda, Heterophyidae) whose larvae cause pigment spots in marine fish. - Ecology 45, 69-75.

Strohbach, U., 1991. Befall von Gastropoden und planktischen Copepoden in der südwestlichen Ostsee. Staatsexamens-Arb. Univ. Hamburg, 113 pp.

Thormann, S. \& Wiederholm, A.-M., 1983. Seasonal occurrence and food resource use of an assemblage of nearshore fish species in the Bothnian Sea, Sweden. - Mar. Ecol. Prog. Ser. 10, 223-229.

Wootton, R. J., 1976. The biology of sticklebacks. Acad. Press, London, $387 \mathrm{pp}$.

Zander, C. D., 1979a. On the biology and food of small-sized fish from the North and Baltic Sea area. I. Investigation on Pomatoschistus pictus (Malm) (Gobiidae) from Helgoland. - Zool. Anz. 202, $413-424$.

Zander, C. D., 1979b. On the biology and food of small-sized fish from the North and Baltic Sea area. II. Investigation of a shallow stony ground off Møn, Denmark. - Ophelia 18, 179-190.

Zander, C. D., 1988. Zur Bedeutung von Kleinfischen im Ökosystem der Ostsee. - Seevögel 9, 51-55.

Zander, C. D., 1990. Prey selection of shallow water fish Pomatoschistus minutus (Gobiidae, Teleostei) in the SW Baltic Sea. - Helgoländer Meeresunters. 44, 147-157.

Zander, C. D., 1991. Akkumulation von Helminthen-Parasiten in Aalmuttern - Zoarces viviparus (L.) (Teleostei) der SW Ostsee. - Seevögel 12, 70-73.

Zander, C. D. \& Döring, W., 1989. The role of gobies (Gobiidae, Teleostei) in the food web of the shallow habitats of the Baltic Sea. In: Proceedings of the $21^{\text {st }}$ European Marine Biology Symposium. Ed. by R. Z. Klekowski, E. Styczyńska-Jurewicz \& L. Falkowski. Polish Academy of Sciences, Institute of Oceanology, Gdansk, 499-508.

Zander, C. D. \& Hagemann, T., 1986. Fluctuation of prey, abundance and biomass of gobies (Gobiidae, Pisces) in a shallow habitat of the western Baltic Sea. - Zool. Anz. 216, 289-304.

Zander, C. D. \& Hagemann, T. 1987. Predation impact and ecological efficiency of Pomatoschistus minutus (Gobiidae, Pisces) from a clay/sand ecotone of the western Baltic Sea. - Zool. Anz. 218, $33-48$.

Zander, C. D., Kollra, G., Antholz, B., Meyer, W. \& Westphal, D., 1984. Small-sized euryhaline fish as intermediate hosts of the digenetic trematode Cryptocotyle concavum. - Helgoländer Meeresunters. 37, 433-443.

Zander, C. D. \& Westphal, D., 1991. Kleinfischparasiten der Ostseeförde Schlei und ihre Einbindung in die Nahrungskette. - Seevögel 12, 4-8.

Zander, C. D. \& Westphal, D., 1992. Nahrungsbeziehungen von vier euryhalinen Kleinfischarten der Ostseeförde Schlei. - Zool. Jb. (Syst. Ökol. Geogr. Tiere) 119, 339-364. 